$1 \quad$ Article

\title{
Unfolding the Apoptotic Mechanism of Antioxidant Enriched-Leaves of Tabebuia pallida in EAC Cells
}

Md. Mahbubur Rahman ${ }^{a}$, Muhammad Ali Khan ${ }^{b}$, A. S. M. Ali Reza', Khaled Mahmud Sujon $^{\mathrm{e}}$, Rokshana Sharmin ${ }^{\mathrm{d}}$, Mamunur Rashid ${ }^{\mathrm{e}}$, Md. Golam Sadik, Md. Abu Reza ${ }^{\mathrm{e}}$, Toshifumi Tsukahara ${ }^{\mathrm{g}}$, Ashik Mosaddik, ${ }^{\mathrm{e}, \mathrm{h}}$ Glenda C Gobe ${ }^{\mathrm{b} *}$ and AHM Khurshid Alam ${ }^{\mathrm{e} *}$

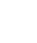

${ }^{a}$ Department of Pharmacy, Varendra University, Rajshahi-6204, Bangladesh;

${ }^{\mathrm{b}}$ School of Biomedical Sciences, University of Queensland, Brisbane, Australia;

${ }^{c}$ Department of Pharmacy, International Islamic University Chittagong, Chittagong-4318, Bangladesh.

${ }^{\mathrm{d}}$ Department of Pharmacy, Jessore University of Science and Technology, Jessore, Bangladesh;

e Department of Pharmacy, University of Rajshahi, Rajshahi-6205, Bangladesh;

fDepartment of Genetic Engineering and Biotechnology, University of Rajshahi, Rajshahi-6205, Bangladesh;

${ }^{\mathrm{g}}$ Graduate School of Advanced Science and Technology and Division of Transdisciplinary Science, Japan Advanced Institute of Science and Technology, 1-1 Asahidai, Nomi City, Ishikawa 923-1292, Japan;

${ }^{\mathrm{h}}$ Department of Clinical Pharmacy, Institute for Research \& Medical Consultations, Imam Abdulrahman Bin Faisal University, Dammam, Saudi Arabia

Email addresses of authors: mrpolash.bd@gmail.com (M.M.R.); rumel.ph@ gmail.com (M.A.K.); alirezaru@gmail.com (A.S.M.A.R.); g.gobe@uq.edu.au (G.C.G); lina2052@gmail.com (R.S.); mrashid@ru.ac.bd (M.R.); gsadik2@yahoo.com (M.G.S.); rezaru@gmail.com (M.A.R.); kmsujongeb@gmail.com (K.M.S); tukahara@jaist.ac.jp (T.T.); mamosaddik@ru.ac.bd (A.M.); khurshid.jaist@gmail.com (A.H.M.K.A.) 
31 * Correspondence: (1) Prof AHM Kurshid Alam, khurshid.jaist@gmail.com; Tel: +880721711110

32 (office); Fax: +880721750064; (2) Professor Glenda C Gobe, g.gobe@uq.edu.au; Tel: 617 3333465159.

34

35 
bioRxiv preprint doi: https://doi.org/10.1101/2021.01.11.426226; this version posted January 11, 2021. The copyright holder for this preprint (which was not certified by peer review) is the author/funder. All rights reserved. No reuse allowed without permission.

36

37

38

39

40

41

42

43

44

45

46

47

48

49

50

51

52

53

54

55

56

\section{Graphical Abstract}

7

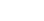

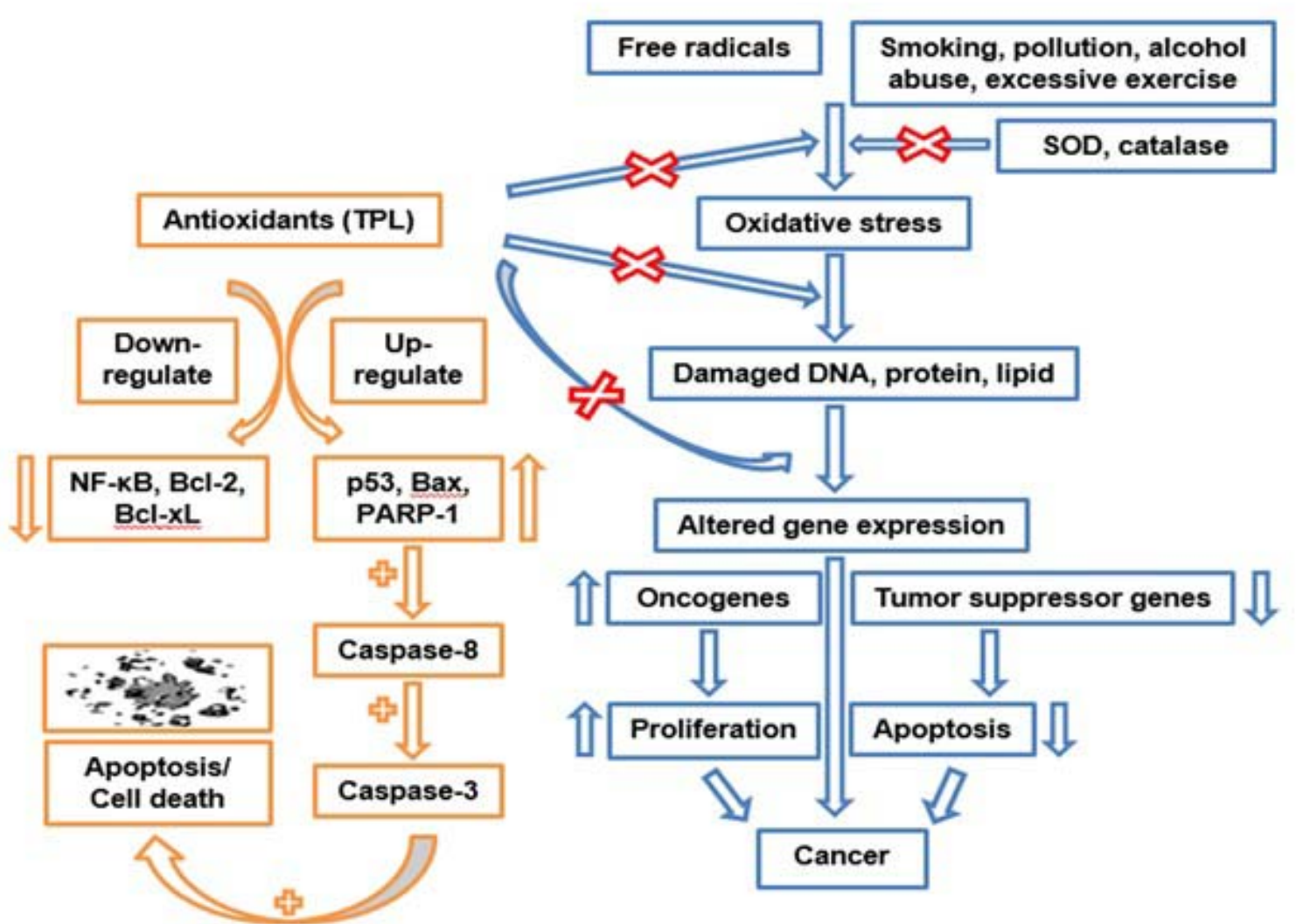




\section{Abstract}

Targeting apoptosis is a promising approach to inhibit the abnormal cell proliferation of cancer progression. Existing anti-apoptotic drugs, many derived from chemical substances, have often failed to combat cancer development and progression. Therefore, identification of apoptosisinducing anticancer agents from plant-derived sources has become a key aim in cancer research. pallida) using an Ehrlich Ascites Carcinoma (EAC) mouse model and compositional analysis by LC-ESI-MS/MS. Dried and powdered T. pallida leaves (TPL), stem bark (TPSB), root bark (TPRB) and flowers (TPF) were extracted with $80 \%$ methanol. Using cultured EAC cells and EAC-bearing mice with and without these extracts, anticancer activities were studied by assessing cytotoxicity and tumor cell growth inhibition, changes in life span of mice, and hematological and biochemical parameters. Apoptosis was analyzed by microscopy and expression of selected apoptosis-related genes (Bcl-2, Bcl-xL, NFk-B, PARP-1, p53, Bax, caspase-3 and -8) using RT-PCR. LC-ESI-MS analysis was performed to identify the major compounds from the most active extracts. In EAC mice compared with untreated controls, the TPL extract exhibited the highest cytotoxicity with significant tumor cell growth inhibition $(\mathrm{p}<0.001)$, reduced ascites by body weight $(\mathrm{p}<0.01)$,

74 increased the life span ( $\mathrm{p}<0.001)$, normalized blood parameters ( $\mathrm{RBC} / \mathrm{WBC}$ counts), and increased 75 the levels of superoxide dismutase and catalase. TPL-treated EAC cells showed apoptotic characteristics of membrane blebbing, chromatin condensation and nuclear fragmentation, and caspase-3 activation, compared with untreated EAC cells. Moreover, annexin V-FITC and propidium iodide signals were greatly enhanced in response to TPL treatment, indicating apoptosis 79 induction. Pro- and anti-apoptotic signaling after TPL treatment demonstrated up-regulated p53, 80 Bax and PARP-1, and down-regulated NFK-B, Bcl-2 and Bcl-xL expression, suggesting that TPL 81 shifts the balance of pro- and anti-apoptotic genes towards cell death. LC-ESI-MS data of TPL 82 showed a mixture of glycosides, lapachol, and quercetin antioxidant and its derivatives that were 
83

84

significantly linked to cancer cell targets. In conclusion, the TPL extract of T. pallida possesses significant anticancer activity. The tumor suppressive mechanism is due to apoptosis induced by activation of antioxidant enzymes and caspases and mediated by a change in the balance of pro- and anti-apoptotic genes that promotes cell death.

Keywords: Tabebuia pallida; EAC cells; LC-MS; apoptosis; caspases; p53; NFk-B

\section{Introduction}

Throughout the globe, causes of death due to cancer are increasing. This is often because of lack of early detection methods and poor prognosis with diagnosis at an advanced rather than an early stage [1]. According to the GLOBOCAN 2018 database, approximately 18.1 million new cancers were diagnosed and 9.6 million cancer deaths occurred in 2018. The WHO estimates that over 29.5 million new cases of cancer will be diagnosed annually, and deaths from cancer will be over 16.5 million a year by 2040 worldwide [2, 3]. Although cancer incidence rates are high in both developed and developing countries, mortality rates due to cancer are extremely high in developing countries. It was estimated that, in 2012 , over $65 \%$ of all cancer deaths throughout the world occurred in lower and middle income countries and the percentage is projected to increase to $75 \%$ by $2030[2,4]$. In the USA, approximately 1,762,450 cancer cases were diagnosed in 2019 , which is the equivalent of more than 4,800 new cases every day. It was estimated that over 606,880 Americans died from cancer in 2019, representing around 1,700 deaths per day [5].This alarming rate of cancer mortality can be reduced with early cancer detection and effective anti-cancer medications.

The characteristics of cancer include abnormal cell proliferation and inhibition of, or resistance to, apoptosis $[6,7]$. Apoptosis occurs through the regulation of distinct types of pro-apoptotic (e.g. Bax, Bid, Bak or Bad) and anti-apoptotic (e.g. Bcl-2, Bcl-xL, Mcl-1) genes [8]. In their review on cancer development, Hanahan and Weinberg reported that the apoptotic trigger occurs when there is 
108 an imbalance between pro- and anti-apoptotic genes, with the imbalance allowing uncontrolled

109 proliferation of cells, cancer growth and progression [7]. The cellular characteristics of apoptosis

110 include cell shrinkage and plasma membrane blebbing, chromatin condensation and DNA

111 fragmentation [9]. The molecular characteristics include activation of caspases, changes in pro- and

112 anti-apoptotic genes, and regulation of p53 and nuclear factor- $\mathrm{BB}(\mathrm{NF \kappa B})$ signaling pathways [10-

113 11]. Apoptosis occurs without any local inflammation, and is therefore the preferred mode of cell

114 death in cancer elimination [12]. Therefore, if apoptosis is clearly understood, it opens a gate to

115 tumor-specific apoptosis therapy.

116 Many natural products contain a variety of bio-active compounds. Their derivatives have been

117 tested for anticancer potential on various preclinical cancer models [13]. From such a screening

118 process, many anticancer drugs have been derived from plants, including vinblastine and vincristine

119 from Catharanthus roseus, taxol from Taxas brevifolia, etoposide and teniposide from

120 Podophyllum species, topotecan and irinotecan from Camptotheca acuminate, 4-ipomeanol from

121 Ipomoea bataatas, and B-lapachone from Tabebuia avellanedae. These plant-based drugs induce

122 apoptosis in various types of cancer $[14,15]$. A major drawback of these drugs in cancer treatment

123 is the indiscriminate killing of both the cancer and normal cells. Therefore, identification of

124 effective anticancer drugs of plant origin with low toxicity to normal cells has gained renewed

125 interest [16].

126 Tabebuia pallida (Lindl.) Miers (T. pallida), commonly known as white trumpet tree, belongs to

127 Bignoniaceae family, and is a species of the genus Tabebuia. T. pallida is widely distributed in

128 northern Mexico, Southern to Northern Argentina, the Caribbean Islands, Cuba, Chile and Paraguay

129 [17]. Although our recent studies on T. pallida showed antimicrobial, antioxidant and anticancer

130 activities [18-20], much remains unknown about its mechanistic role in these activities. Two

131 reviews of multiple Tabebuia species demonstrated the anticancer efficacy against different types of

132 cancers [21, 22]. For instance, the heartwood of T. avellanedae [15], leaves of T. impetiginosa [23],

133 and leaves and flowers of T. rosea [24], have been used successfully against liver, breast, prostate 
134 and ovarian cancers. The stem bark extract of T. avellanedae and T. cassinoides had anticancer

135 activity against Ehrlich Ascites Carcinoma (EAC) bearing mice (EAC mice) [25]. Moreover, $\beta$ -

136 lapachone, isolated from different Tabebuia species, was reported to act as an anticancer agent in a 137 wide variety of tumor cell lines $[22,26]$.

138 The reported in vitro and in vivo biological activities of different Tabebuia species encouraged us to

139 test the mechanism of anticancer activity of different parts (leaves, stem, root bark and flowers) of $T$. 140 pallida in EAC mice. Already our group reported that $T$. pallida leaves (TPL) possess the highest 141 antioxidant activity [18] and show strong anticancer toxicity with significant suppression of tumor

142 cell growth [20]. The current study aimed to ascertain whether or not these anticancer effects were

143 due to the induction of apoptosis, by activating caspases (caspase-3 and 8) and regulating p53 and

144 NFK-B signaling, and to identify the bioactive properties present in the extract that are responsible

145 for the anticancer effect.

146 2. Materials and Methods

\subsection{Plant Collection}

In May 2013, leaves, stem and root bark and flowers of T. pallida were collected from the

149 University campus, Rajshahi University, Bangladesh. Prof. Dr. Mahabubur Rahman, Department of 150 Botany of the same University identified the plant and a voucher specimen of all plant parts was 151 stored at the Herbarium of the Botany Department (Voucher No. MN-03) and the National 152 Herbarium of Bangladesh (Voucher No. 46736). Plant parts were washed in water and shade dried 153 with periodic sun drying for several days. The dried materials were then powdered using a grinding 154 machine (Tinytech, India) and preserved at room temperature until utilized.

$156 \quad 1.5 \mathrm{~L}$ of $80 \%$ methanol was used to soak each powdered plant sample $(500 \mathrm{~g})$ for 7 days with 157 periodic shaking and mixing. Filtration was performed using cotton then Whatman No.1 filter 158 paper. The volume of extract was then reduced with a rotary evaporator (Bibby Sterlin Ltd, UK) 
under reduced pressure at $50{ }^{\circ} \mathrm{C}$ to obtain $30,45,40$ and $35 \mathrm{~g}$ of extracted $T$. pallida leaves (TPL),

160 stem bark (TPSB), root bark (TPRB) and flowers (TPF), respectively.

161

162

163

164

165

166

167

168

169

170

171

172

173

174

175

176

177

178

180

181

182

\subsection{Chemicals}

Taq polymerase, RNaseOUT, dNTPs, TRIzole reagent and Super Script-III reverse transcriptase were from Life Technologies (Invitrogen Bio Services India Pvt. Ltd, Bangalore, India). All other chemicals were of high grade.

\subsection{Cytotoxicity by MTT Assay}

The MTT (3-[4,5dimethylthiazol- 2-yl]-2,5diphenyltetrazolium bromide) colorimetric technique was used to assess the cytotoxicity of TPL, TPF, TPSB and TPRB extracts against EAC cells [9]. In this experiment, EAC cells were collected from 7 day old EAC mice after 1 day of EAC intraperitoneal (i.p.) cell inoculation in healthy mice, and $1 \times 10^{6}$ cells placed per well in $200 \mu \mathrm{L}$ RPMI-1640 media in a 96-well plate. Five different concentrations $(8 \mu \mathrm{g}, 15 \mu \mathrm{g}, 30 \mu \mathrm{g}, 60 \mu \mathrm{g}$, and $120 \mu \mathrm{g} / \mathrm{mL} ; \mathrm{N}=3$ ) of the extracts were added to each well of EAC cells to assess the maximal efficiency. As a control, dimethyl sulfoxide (DMSO), as the sample solvent $(0.1 \% \mathrm{w} / \mathrm{v})$, was utilized. The cells were then incubated at $37{ }^{\circ} \mathrm{C}$ for $24 \mathrm{~h}$ in a $\mathrm{CO}_{2}$ incubator and the MTT assay performed using routine procedures [27]. Subsequently, absorbance was measured at $570 \mathrm{~nm}$. The cytotoxic effects of the extracts were estimated in terms of $\%$ growth inhibition and expressed as $\mathrm{IC}_{50}$ which is the concentration of the tested sample that reduces the absorbance of treated cells by $50 \%$ with reference to the control (untreated) cells. The ratio of cell proliferation inhibition was calculated using the following equation:

$$
\text { Proliferation inhibition ratio }(\%)=(\mathrm{A}-\mathrm{B}) \times 100 / \mathrm{A}
$$

where $\mathrm{A}$ is the $\mathrm{OD}_{570 \mathrm{~nm}}$ of control solution and $\mathrm{B}$ is the $\mathrm{OD}_{570 \mathrm{~nm}}$ of sample solution.

\subsection{In Vivo Antitumor Activity}

\subsubsection{Experimental Animals}


183 Four week old male mice (Swiss albino), 20-25 g body weight, from the International Centre for

184 Diarrheal Disease and Research in Bangladesh (ICDDRB) were housed in propylene cages using a

$18512 \mathrm{~h}$ dark and light cycle and temperature $25 \pm 2{ }^{\circ} \mathrm{C}$. Animals received food and water ad libitum. All

186 mice were accustomed to the laboratory conditions for one week before experimentation. Animals

187 were denied food and water for $12 \mathrm{~h}$ before the experiments.

\subsubsection{Ethics Approval}

The Animal Ethical Committee, Rajshahi University (27/08/RUBCMB) and the Committee of Cell

Research of Rajshahi Medical College, Bangladesh (ref. RMC/ER/2010-2013/01) approved the

191 protocol of using mice as an animal model for cancer investigation.

192

193

194

195

196

197

198

199

200

201

202

203

204

205

\subsubsection{Cell Lines}

Indian Institute of Chemical Biology (IICB), Kolkata, India provided the EAC cells that were cultured in Swiss albino mice as an ascites tumor by bi-weekly i.p. inoculation of $1 \times 10^{6}$ cells/mouse.

\subsubsection{Experimental Design}

There were 7 groups and in each group, there were 12 mice randomly divided. Group I was a control group receiving vehicle only; Group II was a tumor group receiving an i.p. injection of $1 \times 10^{6}$ exponentially growing EAC cells; Groups III, IV, V, VI were tumor-bearing treated groups receiving an i.p. injection of $1 \times 10^{6}$ exponentially growing EAC cells with TPL, TPSB, TPRB, TPF extracts at a dose of $100 \mathrm{mg} / \mathrm{kg} / \mathrm{day}$, respectively; and Group VII was a bleomycin-treated $(0.3$ $\mathrm{mg} / \mathrm{kg} /$ day) tumor-bearing standard group. Exponentially growing EAC cells had been propagated i.p. (bi-weekly) in donor Swiss albino mice and collected from ascites fluid 6-7 days after inoculation of tumor cells [9].

\subsubsection{EAC Cell Administration}


206 EAC cells, collected as above, were diluted in normal saline $(0.9 \%)$ to $1 \times 10^{6}$ cells $/ \mathrm{mL}$ as measured 207 by haemocytometry. Cell viability was determined by Trypan blue $(0.4 \%)$ exclusion assay with 208 results showing $99 \%$ cell viability. Each tested Swiss albino mouse was administrated i.p. with $2091 \times 10^{6}$ of EAC cells in $0.1 \mathrm{~mL}$ saline.

\subsubsection{Determination of Toxic Effect of the Extracts}

211 A total of 25, four week old male Swiss albino mice, 20-25 g body weight, were divided into five 212 groups $(n=5)$, and were used to assess any acute toxicity of the extracts. The test was performed 213 with increasing oral dose concentrations of TPL, TPF, TPSB and TPRB in distilled water (50, 100, 214200,500 and $1,000 \mathrm{mg} / \mathrm{kg}$ body weight) that were administered orally at $20 \mathrm{~mL} / \mathrm{kg}$ to each test 215 group. The normal control group received distilled water $(20 \mathrm{~mL} / \mathrm{kg})$. Following treatment, mice 216 were allowed to feed ad libitum and were observed for $48 \mathrm{~h}$ for any mortality or behavioral changes 217 [28].

\subsubsection{Determination of Inhibition of Cell Growth}

219 In vivo inhibition of tumor cell growth was performed by a modification of the procedure reported 220 by Sur and Ganguly [29]. In this method, 5 days of treatment were continued $24 \mathrm{~h}$ after tumor 221 inoculation. Injection at volume $0.1 \mathrm{~mL} /$ day/mouse was given in each case. After transplantation of 222 tumor cells, four mice out of 12 were sacrificed on the $6^{\text {th }}$ day and tumor cells collected with 223 repeated i.p washing with $0.9 \%$ normal saline. The Trypan blue exclusion method was performed 224 to count the total number of viable tumor cells in the peritoneal cavity using the Cedex cell counter 225 (Roche). Compared to the control (Group II), viable tumor cells of each mouse of the treatment 226 groups were measured. The following formula was used to measure cell growth inhibition:

$$
\% \text { Cell growth inhibition }=\left(1-\frac{\mathrm{T}_{\mathrm{w}}}{\mathrm{C}_{\mathrm{w}}}\right) \times 100
$$




\subsubsection{Determination of Average Survival Time and Tumor Weight}

231 Similar conditions as mention in the previous experiment were adapted to measure these

232 parameters. Weight change up to 20 days of treatment was monitored daily to assess tumor growth.

233 According to the method described previously, host survival time was recorded and expressed as

234 mean survival time in the days and percent increase of life span was calculated [30].

235 Mean survival time (MST) $=\frac{\text { Zsurvival time to days of ageh mouse group }}{\text { Tonal number }}$

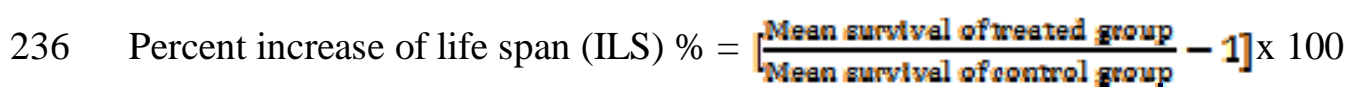

\section{2.5.9. Determination of Hematological Parameters}

238 The hematological parameters (total RBC, WBC, and hemoglobin/Hb content) were measured by

239 standard methods [31]. Blood was collected from the tail vein of each animal on the $12^{\text {th }}$ day after

240 EAC cell inoculation. A hematometer was used to measure the Hb percentage and microscopy with

241 a haemocytometer was used to estimate total WBC and RBC.

\section{2.5.10. Determination of Biochemical Parameters (Superoxide Dismutase and Catalase)}

243 After the collection of blood samples on the $12^{\text {th }}$ day after EAC cell inoculation, the mice were

244 sacrificed. The livers were excised, rinsed in ice-cold normal saline followed by cold $0.15 \mathrm{M}$ Tris-

$245 \mathrm{HCl}(\mathrm{pH} 7.4)$, blotted dry, and weighed. A $10 \% \mathrm{w} / \mathrm{v}$ homogenate was prepared in $0.15 \mathrm{M}$ Tris-HCL

246 buffer followed by centrifugation at $1500 \mathrm{rpm}$ for $15 \mathrm{~min}$ at $4^{\circ} \mathrm{C}$. The supernatant thus obtained was

247 used to estimate superoxide dismutase (SOD) and catalase (CAT) using standard procedures [32, $24833]$.

249 2.5.11. Examination of Morphological Change and Nuclear Damage

250 Cell apoptosis can be marked by plasma membrane blebbing, cell shrinkage, chromatin 251 condensation and nuclear fragmentation (pyknosis), and chromosomal DNA fragmentation [9]. The 252 apoptotic phenomena were observed morphologically by using a fluorescence microscope 
(OlympusiX71, Korea) as reported previously, using Hoechst 33342 staining [9]. In brief, EAC

254 cells collected from Groups II, III, IV, V and VI were washed three times with phosphate buffer

255 saline (PBS). The method of staining used $0.1 \mathrm{~g} / \mathrm{mL}$ of Hoechst 33342 at $37{ }^{\circ} \mathrm{C}$ for 20 min in a dark

256 room, and afterwards cells were washed once more with PBS.

257

258

259

260

261

262

263

264

265

266

267

268

269

270

271

272

273

274

275

276

277

\subsubsection{Measurement of Apoptosis}

DAPI, Annexin V-fluorescein isothiocyanate (Annexin V-FITC) and propidium iodide (PI) triple fluorescent staining for cancer cell apoptosis was performed as described previously [27]. Briefly, $5 \times 10^{3}$ cells per glass bottom dish were seeded and incubated overnight at $37^{\circ} \mathrm{C}$. After that, HeLa cells were treated with $100 \mu \mathrm{g} / \mathrm{mL}$ of TPL for $72 \mathrm{~h}$ at $37^{\circ} \mathrm{C}$. After aspiration, the cells were washed three times with $1 \mathrm{X}$ PBS followed by addition of $1 \mathrm{~mL}$ of $1 \mathrm{X}$ PBS per dish containing the staining solution of DAPI, Annexin V-FITC and PI in a ratio of 2:1:5. The dishes were incubated at 20-25 ${ }^{\circ} \mathrm{C}$ for 5 min under dark conditions, washed with 1X PBS twice and were observed under a confocal laser scanning microscope (Olympus, FV1000, Tokyo, Japan).

\subsubsection{Determination of Involvement of Caspases in T. pallida-Induced Apoptosis}

To confirm the involvement of caspase- 3 and -8 in the $T$. pallida-induced tumor cell death, untreated EAC cells in RPMI 1640 medium were incubated with z-DEVD-fmk (caspase-3 inhibitor, $2 \mu \mathrm{mol} / \mathrm{mL}$ ) and z-IETD-fmk (caspase-8 inhibitor, $2 \mu \mathrm{mol} / \mathrm{mL}$ ) for $2 \mathrm{~h}$ [34]. Then the cells were treated with $120 \mu \mathrm{g} / \mathrm{mL}$ of TPL and incubated at $37{ }^{\circ} \mathrm{C}$ in $5 \% \mathrm{CO}_{2}$ incubator for $24 \mathrm{~h}$. Lastly, an MTT assay determined the cell growth inhibition.

\subsubsection{Isolation and Purification of Total RNA and Synthesis of cDNA}

Total RNA was extracted using published methods [35]. In brief, EAC cells were collected from the peritoneal cavity of mice and washed with ice cold PBS twice followed by adding $0.5 \mathrm{~mL}$ TRIzole reagent (Invitrogen). TRIzole reagent treated EAC cells $\left(1 \times 10^{6}\right.$ cells $\left./ \mathrm{mL}\right)$ were gently vortexed for a few seconds. Then $0.2 \mathrm{~mL} \mathrm{CHCl}_{3}$ was added with vigorous shaking and the mixture was incubated at RT for 2-3 min. This mixture was then centrifuged at $4{ }^{\circ} \mathrm{C}$ and $12,000 \mathrm{rpm}$ for $15 \mathrm{~min}$, 
278 the supernatant collected into an Eppendorf tube and $500 \mu \mathrm{L}$ isopropanol added. The reaction

279 mixture was then incubated for $10 \mathrm{~min}$ at room temperature (RT) and again centrifuged at $4{ }^{\circ} \mathrm{C}$,

$28012,000 \mathrm{rpm}$, for $10 \mathrm{~min}$. After removing the supernatant, the RNA was washed with $75 \%$ ethanol

281 then centrifuged at $4{ }^{\circ} \mathrm{C}, 7,500 \mathrm{rpm}$, for $5 \mathrm{~min}$. After removal of the supernatant, the RNA pellet

282 was dried at RT, and mixed with DEPC-treated RNase free water. The concentration of RNA was

283 estimated by nanodrop (Thermo scientific nanodrop 8000). For cDNA synthesis, $1 \mu \mathrm{g}$ of purified

284 RNA was dissolved with $0.5 \mu \mathrm{g}$ of oligo (dT) primer (Promega), $0.5 \mathrm{mM}$ dNTPs, $1 \times$ first-strand

285 buffer, $5 \mathrm{mM}$ DTT (dithiothreitol), 2 units of RNase OUT (40 unit/ $\mu \mathrm{L}$ ) and 10 units of Super Script

286 III reverse transcriptase (200 unit/ $\mu \mathrm{L})$ (Invitrogen), to make a total volume of $20 \mu \mathrm{L}$. This reaction

287 mixture was incubated at $50^{\circ} \mathrm{C}$ for $1 \mathrm{~h}$, and the reaction terminated by heating at $70{ }^{\circ} \mathrm{C}$ for $15 \mathrm{~min}$.

288 2.5.15. Determination of mRNA Levels of Pro-and Anti-Apoptotic Genes by RT-PCR

289 As described previously, the expression levels of p53, Bax, PARP, Bcl-2, Bcl-XL and NFk-B were

290 determined by RT-PCR [35]. For PCR, specific primers were used to amplify the first-strand cDNA

291 (Table 1). Reagents containing 1X Taq polymerase buffer, 25 pmol each of forward and reverse

292 primers, $2.5 \mathrm{mM}$ of each dNTPs and $0.25 \mathrm{U}$ of platinum Taq polymerase (Tiangen, China) were

293 used to prepare $25 \mu \mathrm{L}$ reaction mixtures. The PCR products of tested genes and housekeeping

294 GAPDH gene were electrophoresed in 1.5\% agarose gels, then the gels were stained with ethidium

295 bromide, and finally visualized by UV transilluminator (Vilber Lourmat).

296 2.5.16. Analysis by HPLC-PDA-ESI-MS/MS

297 The methanol extract of TPL (1 mg) was dissolved in a mixture of acetonitrile/water (50/50, v/v)

298 before filtering through a PTFE $0.20 \mu \mathrm{M}$ syringe filter (Advantec, Tokyo, Japan). Then $2 \mu \mathrm{L}$ filtrate

299 was injected into the HPLC column. For conducting HPLC-PDA-ESI-MS analysis, a Thermo

300 Scientific Surveyor HPLC and an LTQ linear ion trap mass spectrometer (MS; Thermo Scientific

301 Inc. Waltham, MA, USA) with an electrospray ionization (ESI; Burker Esquire 3000 plus) interface

302 at $40{ }^{\circ} \mathrm{C}$, coupled with a photodiode-array detector (PDA) set at $280 \mathrm{~nm}$. UV spectra were scanned 
303

from 200 to $700 \mathrm{~nm}$. A Hypersil GOLD C18 column (100 x $2.1 \mathrm{~mm}$; I.D., $1.9 \mu \mathrm{M})$ with eluent A $\left(\mathrm{H}_{2} \mathrm{O}\right.$ plus $0.05 \%$ trifluoroacetic acid, TFA) and eluent B (acetonitrile plus $0.05 \%$ TFA) was used for chromatographic separation, where the flow rate was $200 \mu \mathrm{L} / \mathrm{min}$ followed by a gradient elution profile: 0-25 min, 90-40\% A; 25-35 min, 40-2 \% A; 38-43 min, 2-40\% A; and 43-45 min, $40 \%$ A. Both the positive and negative modes were considered for ESI experiments. The settings were as follows: mass range measured m/z 150-750; ion trap temperature, $275^{\circ} \mathrm{C}$; Em, $5.0 \mathrm{Kv}$; drying $\mathrm{N}_{2}$, $10 \mathrm{~mL} / \mathrm{min}$; nebulizing $\mathrm{N}_{2}, 30$ psi; sheath gas flow, $35 \mathrm{U}$; capillary voltage, $12 \mathrm{~V}$; and collision gas; helium. Peak area investigation of the observed peaks was performed for primary quantitative analysis. Tentative structural identification was conducted by mass-selecting the ion of interest with a selected ion chromatogram of the individual species. $\mathrm{MS}^{\mathrm{n}}$ spectra were obtained in auto $\mathrm{MS}^{2}$ mode (the product ion of the base peak was selected automatically as a precursor ion for the next stage MS) and provided additional structural information. Instrument operation and data collection were achieved with commercially available software Xcalibur (Finnigan Corp., San Jose, CA. USA).

\subsubsection{In silico Molecular Docking}

\subsubsection{Protein Preparation}

The 3D crystal structures of the active site of HeLa cell 5IAE receptor protein (PDB: 5IAE) [36] and urate oxidase (PDB: 1R4U) [37] were downloaded in PDB format from Protein Data Bank. Then, the structures were prepared and refined using the Protein Preparation Wizard of Maestro V11.1, N.Y, USA using OPLS3 Force Field [38, 39]. A detailed description has been incorporated in the supplementary documents.

\subsubsection{Ligand Preparation}

Identified compounds (D-glucuronic acid, pelargonidin-3-O-glucoside, Quercetin-3-glucoside, Lapachol, Beta-lapachone) were collected from Pubchem databases. Ligprep 2.5 within the Schrödinger Suite 2015 utilizing OPLS_2005 force field was used to build the 3D model of the 
328 ligands. Various ionization states of the compounds were generated at pH $7.0 \pm 2.0$ using Epik 2.2

329 of Schrödinger Suite. Up to 32 possible stereoisomers were retained per ligand for analysis.

330

331

332

333

334

335

336

341

343

\subsubsection{Receptor Grid Generation}

Receptor grids were calculated for the prepared proteins such that various ligand poses would bind within the predicted active site during docking. In Glide of Schrödinger Maestro V11.1, grids were generated keeping the default parameters of Van Der Waals scaling factor of 1.00 and charge cutoff of 0.25 subjected to OPLS3 Force Field. A detailed description has been incorporated in the supplementary documents.

\subsubsection{Glide Standard Precision (SP) Ligand Docking}

SP flexible ligand docking was carried out in Glide [38] within which penalties were applied to non-cis/trans amide bonds. A Van der Waals scaling factor and partial charge cutoff of 0.80 and 0.15 , respectively, were selected for the ligand atoms. Final scoring was performed on energyminimized poses and displayed as the Glide score. A detailed description has been incorporated in the supplementary documents.

\subsection{Statistical Analysis}

Data are demonstrated as mean $\pm \mathrm{SD}$ of $\mathrm{N}=3$ for each experiment. The student's unpaired t-test was performed to estimate significance between the test samples and control. To measure the significant differences among different groups, one-way analysis of variance (ANOVA) followed by a Dunnett's post hoc test was used. $P$ value $<0.05$ was considered as statistically significant. Free Rsoftware version 2.15 .1 (http://www.r-project.org/) and Microsoft Excel 2007 (Roselle, IL, USA) were used for the statistical and graphical evaluations.

\section{Results}

\subsection{Cytotoxic Activity of T. pallida Extracts}


352 The cytotoxic effect of methanol extracts of TPL, TPF, TPSB and TPRB against EAC cells was 353 evaluated by MTT assay where incubation time was $24 \mathrm{~h}$ with $8-120 \mu \mathrm{g} / \mathrm{mL}$ concentrations. All the 354 extracts possessed different dose-dependent cytotoxic activity against EAC cells. Viability of EAC 355 cells was significantly inhibited by all extracts, with maximum inhibition by TPL (86.22\%) 356 compared to other extracts such as TPF (72.88\%), TPSB (76.88\%) and TPRB (62.66\%) at the 357 concentration of $120 \mu \mathrm{g} / \mathrm{mL}$ (Figure 1A). The $\mathrm{IC}_{50}$ (concentration producing 50\% growth 358 inhibition) of the TPL extract was $21.5 \mu \mathrm{g} / \mathrm{mL}$, compared with $\mathrm{IC}_{50}$ values of 46, 37.5 and 57 $359 \mu \mathrm{g} / \mathrm{mL}$ for TPF, TPSB and TPRB extracts, respectively (Figure 1B).

\subsection{Acute Toxicity Studies of T. pallida Extracts on Normal Mice}

361 The primary aim of the acute toxicity studies was to establish the therapeutic index (the ratio 362 between the pharmacologically effective dose and the lethal dose) within the same strain and 363 species [28]. T. pallida extracts were safe at doses as high as $1,000 \mathrm{mg} / \mathrm{kg}$ (p.o.) body weight. The 364 behavior of the mice was observed for the first $3 \mathrm{~h}$, then every $4 \mathrm{~h}$ during the next $48 \mathrm{~h}$ period. The 365 extracts did not induce mortality, behavioral changes, locomotor ataxia and diarrhea or weight loss 366 in mice during the $48 \mathrm{~h}$ observation period. Furthermore, food and water intake did not differ 367 among the groups studied.

\subsection{Effect of T. pallida Extracts on Survival Time and Average Tumor Weight}

369 Tumor weight of EAC mice was calculated in vivo where treatment with TPL, TPF, TPSB and

370 TPRB extracts at the dose of $100 \mathrm{mg} / \mathrm{kg}$ was continued for 20 consecutive days. Among the 371 extracts, TPL treatment showed the greatest tumor weight reduction $(6.16 \pm 0.09 \mathrm{~g})$, which was 372 significant $(p<0.001)$ when compared with untreated EAC mice $(22.4 \pm 0.35 \mathrm{~g})$. The reduction of 373 tumor weight was also observed at various time points (Figure 2). Moreover, the tumor reduction 374 capability of TPL closely resembled that of the standard bleomycin $(6.89 \pm 0.11 \mathrm{~g})$ (Figure 3A). 375 Since the extracts reduced the tumor weight, the effect of these extracts was then tested on the 
survival time in EAC mice. The mean survival time (MST) and life span of the untreated EAC mice

377 (MST $18.03 \pm 1.73$ days) was increased with all extracts (Figure 3B).

\section{8}

379

380

381

382

383

384

385

386

387

388

389

390

391

392

393

394

395

396

397

398

399

400

\subsection{Effect of T. pallida Extracts on Hematological Parameters}

The effect of the extracts on hematological parameters is presented in Table 2. The WBC and RBC count, and the percentage of $\mathrm{Hb}$ were significantly disrupted in EAC mice compared to the normal group. After 12 days of treatment with all extracts, there was a significant $(p<0.05)$ improvement in the hematological parameters of EAC bearing mice with these parameters reverting to normal levels.

\subsection{Effect of T. pallida Extracts on Tumor Cell Growth}

Plant derived extracts having phytochemical components are cytotoxic against tumor cells and show antitumor activity in vivo [8]. Since extracts from different parts of $T$. pallida confirm the presence of bioactive constituents with considerable in vitro cytotoxic effect, we investigated the in vivo effect of TPL, TPF, TPSB and TPRB on EAC mice. The TPL extract showed the greatest and significant $(p<0.001)$ inhibition of tumor cell growth $(71.71 \%)$ in comparison to TPF $(66.42 \%)$, TPSB (63.13\%) and TPRB (57.62\%) at the dose of $100 \mathrm{mg} / \mathrm{kg}$ (i.p.). The standard bleomycin showed $83.10 \%$ tumor cell growth inhibition at the dose of $0.3 \mathrm{mg} / \mathrm{kg}$ (i.p.) (Table 3). This result implies that extracts from the different $T$. pallida plant components, especially the TPL extract, had significant $(p<0.001)$ anticancer activity compared to the standard bleomycin.

\subsection{Effect of TPL Extract on Caspase-3 and -8 in TPL-Induced Apoptosis}

We justified the selection of the TPL extract for further study because it was most effective in inhibiting EAC cell growth, and when the induction of apoptosis was measured using Hoechst stain and fluorescence microscopy, the characteristic morphological features of apoptosis of treated EAC cells were regularly identified when compared to controls (Figure 4). Caspase inhibitors, z-DEVDfmk (caspase-3 inhibitor) and z-IETD-fmk (caspase-8 inhibitor), were used to check the effect of 
TPL on these caspases. TPL treatment caused $86.22 \%$ suppression of tumor cell growth, which was

402 significantly $(p<0.01)$ reduced to $59.00 \%$ and $66.00 \%$ in the presence of caspase-3 and -8

403 inhibitors, respectively (Figure 5) suggesting that induction of apoptosis by TPL was caspase-3 and

$404-8$ dependent.

405

406

407

408

409

410

411

412

413

414

415

416

417

418

419

420

421

422

423

424

425

\subsection{Effect of TPL on Cell Apoptosis}

The apoptotic effect of TPL was further confirmed using HeLa cell apoptosis by evaluating DAPI, Annexin V-FITC, and PI triple fluorescence staining. DAPI is used as a marker of cell membrane permeability seen in very late apoptosis; whereas, Annexin V-FITC staining can identify apoptosis at an early stage [27]. In this study, DAPI, Annexin V-FITC, and PI signals could barely be detected in control cells (without treatment), while strong fluorescence densities were observed in response to treatment, indicating that TPL is able to induce HeLa cell apoptosis (Figure 6) through early and late stages.

\subsection{Effect of TPL on Pro- and Anti-Apoptotic Gene Expression}

Since it is widely reported that different pro-and anti-apoptotic genes play a vital role in induction of apoptosis, we therefore evaluated the involvement of TPL on anti-apoptotic genes (NFK-B, Bcl2, and Bcl-xL) and pro-apoptotic genes (p53, PARP-1, and Bax). In our study, TPL treatment significantly $(p<0.05)$ increased the mRNA levels of pro-apoptotic p53, PARP-1, and Bax and decreased the expression of $\mathrm{NF \kappa B}, \mathrm{Bcl}-2$ and $\mathrm{Bcl}-\mathrm{xL}$ (Figure 7A, 7B, 7C). This observation confirmed that TPL treatment leads to a pro-apoptotic balance in pro- and anti-apoptotic genes, thereby promoting apoptosis of EAC cells.

\subsection{Effect of TPL on Antioxidant Enzymes (SOD and CAT)}

As shown in Figure 8A, SOD levels in the liver of EAC bearing mice significantly decreased by $37.41 \%$ in comparison with the non-EAC control mice $(p<0.001)$. Treatment of EAC mice with TPL $(100 \mathrm{mg} / \mathrm{kg})$ increased SOD by $35.06 \%$, as compared to that of the untreated EAC mice $(p<0.01)$. The CAT levels in the EAC mice were significantly decreased by $59.1 \%$ in comparison 
with the non-EAC mice $(p<0.001)$. Administration of TPL $(100 \mathrm{mg} / \mathrm{kg})$ to EAC mice increased the

427 CAT levels by $50.22 \%$ when compared to the EAC control mice $(p<0.01)$ (Figure $8 \mathrm{~B})$.

\subsection{Chemical Characterization of the TPL Extract by LC-PDA-ESI-MS/MS}

A non-targeted LC-PAD-MS/MS chemical analysis of the highly active TPL extract was performed to identify the tentative components that might be considered to show the apoptosis leading anticancer effect. Figure 7A shows the major UV peaks of TPL at 280nm of HPLC spectrum. Compounds were tentatively identified based on parent molecular ions, UV values, retention times and elution order, as well as the fragmentation pattern described in the literature. The UV and MS data of the major compound, quercetin-3-glucoside (4), which were established on the basis of SIM analysis and by comparison with the published data [40], are shown in the Figure 9A and 9B. It was not possible to quantify the identified compounds in this mixture by LC/UV due to the overlapping and broad peaks, as well as a lack of corresponding commercial standards. Thus, the percentage of relative peak area of the tentatively identified compounds was used to determine the relative amounts of the constituents in TPL extract. The results indicated the presence of D-glucuronic acid, pelargonidin-3-O-glucoside, quercetin-3-glucoside, quercetin 3-O-(2'”-O-acetyl) glucoside, lapachol, $\beta$-lapachone, Coumarin glycoside and some unknown compounds (Table 4).

\subsection{In silico Molecular Docking for Anticancer Activity of Compounds Present in TPL}

Computer aided anticancer activity was performed to assess the binding pattern of molecules with the amino acids present in the active pocket of the protein. In this study, we used 3D crystal structures of the active site of the HeLa cell 5IAE receptor protein. Among the compounds obtained in TPL, pelargonidin-3-O-glucoside showed the highest docking score (-6.566) followed by Dglucuronic acid (-5.287), quercetin-3-glucoside (-5.238), beta-lapachone (-4.788), and lapachol (4.092) with glide emodel (-59.813) and glide energy (-46.383) against active site of HeLa cell 5IAE receptor protein. The results of the docking analysis were depicted in Table 5 and Figure 10A-10E. 
450 The anticancer activity of the compounds was in the following order: pelargonidin-3-O-glucoside>

451 D-glucuronic acid> quercetin-3-glucoside> beta-lapachone> lapachol.

452

453

454

455

456

457

458

\subsection{In silico Molecular Docking for Antioxidant Activity}

Computational study was performed to find out potential antioxidant molecules virtually. Grid and ligand based molecular docking program was used to assess the binding pattern of molecules with the amino acids present in the active pocket of the protein. The docking study was performed using the identified active compounds of TPL to the active site of urate oxidase (Uox) enzyme receptor (PDB: 1R4U). Pelargonidin-3-O-glucoside had the highest docking score (-6.42) with glide emodel (-59.752) and glide energy (-42.743) for binding with Uox (PDB: 1R4U) Table 5. The docking score of d-glucuronic acid, quercetin-3-glucoside, beta-lapachone, lapachol was -5.54, -5.396, 5.094 and -4.678 , respectively (Figure 11A-11E). The antioxidant activity of the compounds was in the following order: pelargonidin-3-O-glucoside> D-glucuronic acid> quercetin-3-glucoside> betalapachone> lapachol.

\section{Discussion}

Cancer is a disease of unrestrained cell proliferation, where cancer cells develop the ability to escape apoptosis by utilizing various survival pathways [7]. Thus, in cancer therapy, the induction of apoptosis in cancer cells can be an effective treatment strategy. Inadequate effectiveness of existing chemotherapy drugs has lead to researchers investigating new apoptosis-inducing drugs to combat cancers.

Plant-derived natural products, crude extracts and/ or pure isolated compounds, have great potential in cancer treatment due to their capability to modulate apoptosis [41]. In our earlier observations, we confirmed that TPL contains the highest polyphenolic content, antioxidant and antiproliferative properties $[18,20]$. The current study is an ongoing screening of our previous outcomes to determine whether the antioxidant enriched TPL possesses anticancer mechanisms at the molecular 
475 level in EAC mice. For the first time, this study provides evidence for the apoptosis-inducing

476 capability of TPL and the LC-ESI-MS analysis of TPL extract for active content.

477 At first, various plant parts of T. pallida (TPL, TPF, TPSB and TPRB) were investigated for their

478 cytotoxic activity. The TPL extract possessed significant cytotoxicity, presumably because of the

479 presence of some highly active bioactive compounds. It has been reported that the phytochemical

480 components existing in plants show antitumor activity via multiple anticancer pathways [42].

481 Moreover, cytotoxic compounds cause apoptosis by controlling signaling mechanisms such as

482 activation of caspases under the regulation of the Bcl-2 family of proteins or upregulated expression

483 of pro-apoptotic receptors on cancer cells, which causes activation of apoptotic signaling pathways

484 by subsequent interaction with their ligands. Mitsuhashi et al. reported that phytochemicals such as

485 polyphenolic compounds have cytotoxic and antioxidant properties [43]. Our previous findings of

486 in vitro antioxidant activity of $T$. pallida support the current results of cytotoxic activity, especially

487 of TPL extracts [18].

488 A reliable benchmark for judging the effectiveness of some antitumor drugs is the reduction of

489 tumor cell growth, decreased tumor weight, decrease of WBC and the extension of life span of the

490 treated animals [44]. Although all extracts of T. pallida had antitumor activity, the TPL extract was

491 most active because it significantly suppressed the tumor cell growth, reduced the tumor weight and

492 increased the life span of EAC mice.

493 Myelosuppression and anemia are major complications usually encountered in cancer chemotherapy

494 due to decrease of $\mathrm{RBC}$ or the percentage of $\mathrm{Hb}$ in the host, resulting in iron deficiency in

495 hemolytic or myelopathic conditions [45]. The treatment with different parts of T. pallida,

496 especially TPL, improved $\mathrm{Hb}$ content and RBC levels, suggesting that these extracts possess

497 protective action on the hemopoietic system.

498 Antioxidant enzymes such as SOD and CAT play an important role in maintaining the correct

499 balance of free radicals in cells. These enzymes are involved in the clearance of superoxide and 
500 hydrogen peroxide $\left(\mathrm{H}_{2} \mathrm{O}_{2}\right)$. SOD catalyses the attenuation of superoxide into $\mathrm{H}_{2} \mathrm{O}_{2}$, which is 501 eliminated by CAT [46]. It has been reported that a decrease in SOD activity in EAC-bearing mice 502 was due to loss of $\mathrm{Mn}^{2+} \mathrm{SOD}$ activity in EAC cells and the loss of mitochondria, resulting in a 503 decrease in total SOD activity in the liver. A small amount of CAT in tumor cells was reported [47]. 504 Moreover, tumor growth is inhibited because of inhibition of SOD and CAT activities [32]. In the 505 present study, similar findings were observed in EAC-bearing mice. The TPL treatment 506 significantly increased the SOD and CAT levels. The in vitro [18], in vivo and in silico antioxidant 507 activity of TPL was due to phytochemicals present in the TPL.

508 In addition, a compositional analysis of TPL (highly active part) was performed using LC-PDA509 MS/MS to identify which phytochemicals are responsible for the anticancer activity. In the present 510 study, the apoptotic activity of TPL could be attributed to the presence of quercetin-3-glucoside 511 (major compound), pelargonidin-3-O-glucoside and/or lapachol derivatives, which were identified 512 from TPL based on HPLC-MS evidence. The major phytochemical quercetin-3-glucoside and its 513 derivatives and related compounds have well documented anticancer effects [48, 49]. Moreover, 514 other compounds such as pelargonidin, lapachol and its derivatives also showed significant 515 anticancer and pro-apoptotic effects against different cell lines [50, 51]. However, on the basis of 516 the chemical profile, the methanol extract of TPL might also possess chemical entities or 517 phytochemicals that interact among themselves, perhaps resulting in a synergistic effect, or in fact a 518 cancelling effect, on their anticancer action. This needs further study. To corroborate the anticancer 519 activity of TPL, in silico molecular docking was performed to obtain a good picture of antioxidant 520 and anticancer compounds identified in T. pallida. In computer-aided drug design, in silico 521 molecular docking is a pivotal tool which allows predicting the binding activity of compounds 522 against particular proteins [52]. In addition, the possible molecular mechanism of actions of 523 different pharmacological activities is determined comprehensively through molecular docking. In 524 our study, a grid-based docking method was used to analyze the binding modes of the molecule 525 with the amino acids present in the active pocket of the protein [53]. The interaction between the 
compounds and the active sites was assessed with docking analysis in Schrodinger Suite v 11.1. In

527 this study, five major bioactive compounds of TPL interacted against two target receptors or 528 enzymes, namely HeLa cell 5IAE receptor protein (PDB: 5IAE) and Uox enzyme receptor (PDB:

529 1R4U). Among these, pelargonidin-3-O-glucoside had the highest docking scores against Uox (530 6.42) and HeLa cell 5IAE receptor protein (-6.566). The negative and low value of the free binding 531 energy $(-6.42,-6.566)$ has proved to be a strong favorable connection with the respective receptors.

532 From these results, the phytocompounds of $T$. pallida that were studied may, in part, be responsible 533 for the anticancer and antioxidant activities through interactions with these target enzymes or 534 receptors.

535 Cancer cells adapt different approaches to escape death, including modified expression of genes and 536 proteins associated with cell life. To halt or stave off the apoptotic process is a common survival 537 strategy of cancer cells, where deregulation of pro-apoptotic genes [54] or hyper-activation of anti538 apoptotic genes takes place [7]. In our study, induction of apoptosis by TPL was confirmed by 539 observing the alteration in nuclear morphology and cell shape in TPL-treated EAC cells compared 540 to that of the untreated EAC cells. A series of caspases, such as caspase-3, $-6,-7,-8$ and -9 , are 541 involved in morphological changes and apoptotic cell death [55]. In this study, the activity of the 542 caspase-3 and caspase-8 were blocked by the z-DEVD-fmk and z-IETD-fmk inhibitors, 543 respectively. The results indicated that TPL induced caspase-dependent apoptosis by activating 544 caspase-3 and caspase-8 significantly. In another apoptotic pathway, cellular commitment to 545 apoptosis depends somewhat on the balance between proteins that intercede cell cycle arrest and 546 cell death (e.g. p53, PARP-1, Bax) and proteins that are anti-apoptotic (e.g. Bcl-2 and Bcl-xL) [8, 547 56]. The pro-apoptotic gene, p53, is a key arbiter of apoptosis after DNA damage and cell cycle 548 arrest [57]. Its activity subsequently allows Bcl-2 family members, particularly pro-apoptotic Bax, 549 to pass an apoptotic signal to the mitochondria, eventually leading to cell death [58]. The current 550 study indicated that there was p53 up-regulatio, down-regulation of Bcl-2 and Bcl-xL, and 551 increased up-regulation of PARP-1 and Bax. As a result, the increased ratio of Bax/Bcl-2 
552 consequently increased cell death. In a similar way, a decrease in NFK-B signaling promoted

553 apoptosis in association with decreased expression of Bcl-2 and Bcl-xL.

554 Furthermore, the effect of the TPL on cell apoptosis was evaluated using DAPI, Annexin V-FITC,

555 and PI triple fluorescence staining [27]. In this study, DAPI, Annexin V-FITC, and PI signals were

556 negligible in control cells (without treatment), while strong fluorescence densities were observed in

557 response to treatment, verifying the capacity of TPL extractsto induce cell apoptosis.

558 Taking all the results together, we propose a mechanistic pathway of anticancer potential of TPL 559 where antioxidant-enriched TPL blocks oxidative stress by scavenging free radicals [18]. This 560 triggers apoptosis by regulating the inhibition of NFK-B and its target genes Bcl-2 and Bcl-xL and 561 increasing p53 and its target genes PARP-1 and Bax. An increase in p53 ultimately activates 562 caspase-3 and-8, which induces apoptotic cell death. Phytochemicals with antioxidant potential 563 were identified in TPL. Collectively, these outcomes support the established folkloric value and 564 popularity of $T$. pallida. Therefore, $T$. pallida can be considered as a potential candidate for possible 565 therapeutic intervention in cancer.

\section{5. Conclusions}

567 In this study using a pre-clinical mouse model, the TPL extract of $T$. pallida showed anticancer 568 activity by inhibiting the growth of tumor cells. The TPL treatment-induced apoptosis was 569 associated with activation of caspases-3 and -8 , and was perhaps mediated by the regulation of p53 570 and NFk-B. The LC-MS/MS profiling of TPL indicated the presence of different bioactive 571 compounds, some of which were antioxidant, with a long history of use as anticancer drugs. In light 572 of these data, TPL contains apoptotic pathway-inducing molecules. Computational study of the 573 isolated compound from TPL revealed favorable anticancer and antioxidant activities through 574 interactions with target enzymes or receptors. A more extensive study is needed to identify 575 individual mechanisms of action of precise bioactives of the TPL extract for their anti-apoptotic 576 application in cancer therapy. 
578 Conflicts of Interest: The authors declare no conflict of interest.

579

580 Acknowledgments: The authors are grateful to IICB, Kolkata, India, for providing the EAC cells,

581 Central Science Laboratory of Rajshahi University, Bangladesh for giving support in fluorescence

582 microscopy and also to ICDDRB, for supplying the experimental mice with standard mice pellets.

583 We also thank Dr. AHM Mahabubur Rahman, Professor, Department of Botany, University of

584 Rajshahi and National Herbarium, Dhaka, Bangladesh for the identification of the plant. The

585 authors want to thank Dr. Syed Rashel Kabir, Professor, Department of Biochemistry \& Molecular

586 Biology, for his support in MTT assay.

587 Funding: This research did not receive any specific grant from funding agencies in the public,

588 commercial, or not-for-profit sectors. 


\section{References}

592

593 [1]. J. Wardle, K. Robb, S. Vernon, J. Waller, Screening for prevention and early diagnosis of 594 cancer, Am. Psychol. 70 (2015) 119-133.

[2]. S.C. Shah, V. Kayamba, Jr. R.M. Peek, D. Heimburger, Cancer control in low- and middle596 income countries: is it time to consider screening?, J. Global. Oncol. 5 (2019) 1-8.

[3]. F. Bray, J. Ferlay, I. Soerjomataram, R. L. Siegel, L. A. Torre, A. Jemal, Global Cancer

Statistics 2018: GLOBOCAN estimates of incidence and mortality worldwide for 36 cancers in 185 countries, CA Cancer J. Clin. 68 (2018) 394-424.

[4]. The Lancet, GLOBOCAN 2018: Counting the toll of cancer, Lancet 392 (2018) 985.

[6]. S. H. Kaufmann, G. J. Gores, Apoptosis in cancer: cause and cure, Bio Essays 22 (2000) 10076041017. 
614 [10]. D. R. Mcilwain, T. Berger, T. W. Mak, Caspase Functions in cell death and disease. Cold 615 Spring Harb. Perspect. Biol. 7 (2013) a026716.

616 [11]. Garg, B. B. Aggarwal, Nuclear transcription factor-kappa B as a target for cancer drug 617 development, Leukemia 16 (2002) 1053-1068.

618 [12]. R. T. Bree, C. Stenson-Cox, M. Grealy, L. Byrnes, A. M. Gorman, A. Samali, Cellular 619 longevity: role of apoptosis and replicative senescence, Biogerontology 3 (2002) 195-206.

620 [13]. C. G. Joshi, M. Gopal, N. S. Kumari, Antitumor activity of hexane and ethyl acetate extracts 621 of Tragia involucrate, Int. J. Cancer Res. 7 (2011) 267-277.

622 [14]. G. M. Cragg, D. J. Newman, Natural products: a continuing source of novel drug leads, 623 Biochim. Biophys. Acta 1830 (2013) 3670-3695.

624 [15]. M. J. Nirmala, A. Samundeeswari, P. D. Sankar, Natural plant resources in anti-cancer 625 therapy-A review, Res. Plant Biol. 1 (2011) 1-14.

626 [16]. S. K. Chauthe, S. B. Bharate, G. Periyasamy, A. Khanna, K. K. Bhutani, P. D. Mishra, I. P. 627 Singh, One pot synthesis and anticancer activity of dimericphloroglucinols, Bioorg. Med. Chem. 628 Lett. 22 (2012) 2251-2256.

629 [17]. F. J. Jiménez-González, L. A. Veloza, J. C. Sepúlveda-Arias, Anti-infectious activity in plants 630 of the genus, Tabebuia, Univ. Sci. 18 (2013) 257-267.

631 [18]. M. M. Rahman, M. B. Islam, M. Biswas, A. H. M. K. Alam, In vitro antioxidant and free 632 radical scavenging activity of different parts of Tabebuia pallida growing in Bangladesh, BMC Res. 633 Notes 8 (2015) 621. 
634 [19]. M. M. Rahman, A. S. M. S. Hossain, M. A. Khan, M. N. Haque, S. Hosen, S. A. Mou, A. H.

635 M. K. Alam, A. Mosaddik, In-vitro evaluation of antibacterial activity of Tabebuia pallida against

636 multi-drug resistant bacteria, J. Pharmacogn. Phytochem. 5 (2016) 464-467.

637 [20]. M. M. Rahman, A. S. M. S. Hossain, G. M. Mostofa, M. A. Khan, R. Ali, A. Mosaddik, M. G.

638 Sadik, A. H. M. K. Alam, Evaluation of anti-ROS and anticancer properties from Tabebuia pallida

639 L. (Bignoniaceae) leaves, Clin. Phytosci. 5 (2019) 17.

640 [21]. R. Kaur, K. Kapoor, H. Kaur, Plants as a source of anticancer agents, J. Nat. Prod. Plant 641 Resour. 1 (2011) 119-124.

642 [22]. H. J. Woo, K. Y. Park, C. H. Rhu, W. H. Lee, B. T. Choi, G. Y. Kim, Y. M. Park, Y. H. Choi, 643 Beta-lapachone, a quinone isolated from Tabebuia avellanedae, induces apoptosis in Hep-G2 644 hepatoma cell line through induction of Bax and activation of caspase, J. Med. Food 9 (2006) 161645168.

646 [23]. Bhanot, R. Sharma, M. N. Noolvi, Natural sources as potential anti-cancer agents: A review, 647 Int. J. Phytomed. 3 (2011) 09-26.

648 [24]. S. Solomon, N. Muruganantham, M. N. Senthamilselvi, Anti-cancer activity of Tabebuia rosea 649 (flowers) against human liver cancer, Int. J. Pharm. Biol. Sci. 5 (2015) 171-174.

650 [25]. M. L. Queiroz, M. C. Valadares, C. O. Torello, A. L. Ramos, A. B. Oliveira, F. D. Rocha, V. 651 A. Arruda, W. R. Accorci, Comparative studies of the effects of Tabebuia avellanedae bark extract 652 and $\beta$-lapachone on the hematopoietic response of tumour-bearing mice, J. Ethnopharmacol. 117 653 (2008) 228-235.

654 [26]. J. I. Lee, D. Y. Choi, H. S. Chung, H. G. Seo, H. J. Woo, B. T. Choi, Y. H. Choi, Beta655 lapachone induces growth inhibition and apoptosis in bladder cancer cells by modulation of Bcl-2 656 family and activation of caspases, Exp. Oncol. 28 (2006) 30-35. 
657 [27]. A. Rahim, M. G. Mostofa, M. G. Sadik, M. A. A. Rahman, M. I. Khalil, T. Tsukahara, K.

658 Nakagawa-Goto, A. H. M. K. Alam, The anticancer activity of two glycosides from the leaves of 659 Leea aequata L., Nat. Prod. Res. (2020) 1-6.

660 [28]. R. Zahan, B. Alam, M. Islam, G. C. Sarker, N. C. Chowdhury, S. B. Hosain, M. A. Mosaddik, 661 M. Jesmin, E. Haque, Activity of Alangium salvifolium flower in ehrlich ascites carcinoma bearing 662 mice. Int. J. Cancer Res. 7 (2011) 254ロ 262.

663 [29]. P. Sur, D. K. Ganguly, Tea Plant Root Extract (TRE) as an antineoplastic agent, Planta Med. $66460(1994) 106-109$.

665 [30]. B. J. Abbot, Bioassay of plant extracts for anticancer activity, Cancer Treat. Rep. 60 666 (1976)1007-1010.

667 [31]. J. A. Khanam, M. F. Islam, M. Jesmin, M. M. Ali, Antineoplastic activity of acetone 668 semicarbazone (ASC) against Ehrlich ascites carcinoma (EAC) bearing mice, J. Natn. Sci. 669 Foundation Sri Lanka 38 (2010) 225-231.

670 [32]. M. Gupta, U. K. Mazumder, R. S. Kumar, T. Sivakumar, M. L. M. Vamsi, Antitumor activity 671 and antioxidant status of Caesalpinia bonducella against Ehrlich ascites carcinoma in Swiss albino 672 mice, J. Pharmacol. Sci. 94 (2004) 177-184.

673 [33]. M. S. Rahman, M. B. Alam, Y. H. Cho, J. C. Yoo, Anticancer activity and antioxidant 674 potential of Aponogeton undulatus against Ehrlich ascites carcinoma cells in Swiss albino mice, 675 Oncology Let.14 (2017) 3169-3176.

676 [34]. Y. Wu, D. Wang, Y. Wang, F. Ren, D. Chang, Z. Chang, B. Jia, Caspase 3 is activated 677 through caspase 8 instead of caspase 9 during H2O2-induced apoptosis in HeLa cells, Cell Physiol. 678 Biochem. 27 (2011) 539-546. 
679 [35]. A. H. M. K. Alam, H. Suzuki, T. Tsukahara, Retinoic acid treatment and cell aggregation 680 independently regulate alternative splicing in P19 cells during neural differentiation, Cell Biol. Int. $68134(2010) 631-643$.

682 [36]. Z. Luo, A. Valeru, S. Penjarla, B. Liu, I. Khan, Synthesis, anticancer activity and molecular 683 docking studies of novel pyrido[1,2-a]pyrimidin-4-one derivatives, Synth. Commun. 49 (2019) $684 \quad 2235-2243$.

685 [37]. J. J. Maciag, S. H. Mackenzie, M. B. Tucker, J. L. Schipper, P. Swartz, A. C. Clark, Tunable 686 allosteric library of caspase-3 identifies coupling between conserved water molecules and 687 conformational selection, Proc. Natl. Acad. Sci. U S A 113 (2016) E6080-e6088.

688 [38]. M. J. Uddin, A. S. M. A. Reza, M. Abdullah-Al-Mamun, M. S. H. Kabir, M. S. Nasrin, S. 689 Akhter, M. S. I. Arman, M. A. Rahman, Antinociceptive and Anxiolytic and Sedative Effects of 690 Methanol Extract of Anisomeles indica: An Experimental Assessment in Mice and Computer Aided 691 Models, Front. Pharmacol. 9 (2018) 246.

692 [39]. M. Adnan, M. N. U. Chy, A. T. M. Kamal, K. A. A. Chowdhury, M. A. Rahman, A. S. M. A. 693 Reza, M. Moniruzzaman, S. R. Rony, M. S. Nasrin, M. O. K. Azad, C. H. Park, Y. S. Lim, D. H. 694 Cho, Intervention in Neuropsychiatric Disorders by Suppressing Inflammatory and Oxidative Stress 695 Signal and Exploration of In Silico Studies for Potential Lead Compounds from Holigarna caustica 696 (Dennst.) Oken leaves, Biomolecules 10 (2020) 561.

697 [40]. G. A. Jang, H. W. Kim, M. K. Lee, S. Y. Jeong, A. R. Bak, D. J. Lee, J. B. Kim, 698 Characterization and quantification of flavonoid glycosides in the Prunus genus by UPLC699 DADQTOF/MS, Saudi J. Biol. Sci. 25 (2018) 1622-1631.

700 [41]. S. Fulda, Modulation of apoptosis by natural products for cancer therapy, Planta Med. 76 701 (2010) 1075-1079. 
702 [42]. D. Lamoral-Theys, L. Pottier, F. Dufrasne, J. Nève, J. Dubois, A. Kornienko, R. Kiss, L. 703 Ingrassia, Natural polyphenols that display anticancer properties through inhibition of kinase 704 activity, Curr. Med. Chem. 17 (2010) 812-825.

705 [43]. S. Mitsuhashi, A. Saito, N. Nakajima, H. Shima, M. Ubukata, Pyrogallol structure in 706 polyphenols is involved in apoptosis-induction on HEK293T and K562 cells, Molecules 13 (2008) $707 \quad 2998-3006$.

708 [44]. D. Clarkson, J. H. Burichenal, Preliminary screening of antineoplastic drugs, Prog. Clin. 709 Cancer. 1 (1965) 625-629.

710 [45]. S. R. Aravind, M. M. Joseph, S. Varghese, P. Balaram, T. T. Sreelekha, Antitumor and 711 immune potentiating activity of polysaccharide PST001 Isolated from the seed kernel of 712 Tamarindus indica: an in vivo study in mice, Sci. World J. 2012 (2012) 361-382.

713 [46]. T. H. Rushmore, C. B. Picket, Glutathione-S-transferase, structure, regulation, and therapeutic 714 implication, J. Biol. Chem. 268 (1993) 11475-11478.

715 [47]. S. L. Marklund, N. G. Westman, E. Lundgren, G. Roos, Copper- and zinc-containing 716 superoxide dismutase, manganese-containing superoxide dismutase, catalase, and glutathione 717 peroxidase in normal and neoplastic human cell lines and normal human tissues, Cancer Res. 42 718 (1982) 1955-1961.

719 [48]. Maalik, F. A. Khan, A. Mumtaz, A. Mehmood, S. Azhar, M. Atif, S. Karim, S. Altaf, I. Tariq, 720 Pharmacological applications of quercetin and its derivatives: A short review, Trop. J. Pharm. Res. $72113(2014) 1561-1566$.

722 [49]. F. C. Maiyo, R. Moodley, M. Singh, Cytotoxicity, antioxidant and apoptosis studies of 723 quercetin-3-O glucoside and 4-( $\beta$-D-glucopyranosyl-1 $\rightarrow 4-\alpha$-L-rhamnopyranosyloxy)-benzyl 724 isothiocyanate from moringaoleifera, Anticancer Agents Med. Chem. 16 (2016) 648-656. 
725 [50]. F. Epifano, S. Genovese, S. Fiorito, V. Mathieu, R. Kiss, Lapachol and its congeners as 726 anticancer agents: a review, Phytochem. Rev. 13 (2013) 37-49.

727 [51]. N. Karthi, T. Kalaiyarasu, S. Kandakumar, P. Mariyappana, V. Manju, Pelargonidin induces 728 apoptosis and cell cycle arrest via a mitochondria mediated intrinsic apoptotic pathway in HT29 729 cells, RSC Adv. 6 (2016) $45064-45076$.

730 [52]. S. Khan, M. Nazir, N. Raiz, M. Saleem, G. Zengin, G. Fazala, H. Saleem, M. Mukhtara, M. I.

731 Tousif, R. B. Tareen, H. H. Abdallah, F. M. Mahomoodally, Phytochemical profiling, in vitro 732 biological properties and in silico studies on Caragana ambigua stocks (Fabaceae): A 733 comprehensive approach, Ind. Crops Prod. 131 (2019) 117-124.

734 [53]. G. K. Veeramachaneni, K. K. Raj, L. M. Chalasani, S. K. Annamraju, B. Js, V. R. Talluri, 735 Shape based virtual screening and molecular docking towards designing novel pancreatic lipase 736 inhibitors, Bioinformation 11(2015) 535.

737 [54]. S. W. Fesik, Promoting apoptosis as a strategy for cancer drug discovery, Nat. Rev. Cancer 5 738 (2005) 876-885.

739 [55]. D. Graf, J. G. Bode, D. Häussinger, Caspases and receptor cleavage, Arch. Biochem. Biophys. $740 \quad 462(2007) 162-170$.

741 [56]. P. Giannakakou, R. Robey, T. Fojo, M. V. Blagosklonny, Low concentrations of paclitaxel 742 induce cell type-dependent p53, p21 and G1/G2 arrest instead of mitotic arrest: molecular 743 determinants of paclitaxel-induced cytotoxicity, Oncogene 20 (2001) 3806-3813.

744 [57]. K. Nakano, K. H. Vousden, PUMA, a novel proapoptotic gene, is induced by p53, Mol. Cell 7 745 (2001) 683-694.

746 [58]. J. Yu, L. Zhang, PUMA, a potent killer with or without p53, Oncogene 1 (2008) S71-83. 
749 Table 1: A list of primers with their upstream and downstream sequences and their subsequent 750 length of amplified products

\begin{tabular}{|c|c|c|c|}
\hline Genes & Upstream primer sequence & Downstream primer sequence & $\begin{array}{l}\text { Length of } \\
\text { amplified } \\
\text { products }\end{array}$ \\
\hline $\mathrm{Bcl}-2$ & 5'-GTGGAGGAGCTCTTCAGGGA-3' & 5'AGGCACCCAGGGTGATGCAA-3' & $304 \mathrm{bp}$ \\
\hline Bcl-xL & 5'-TTGGACAATGGACTGGTTGA-3' & 5'-GTAGAGTGGATGGTCAGTG-3' & $\begin{array}{c}780 \text { bp } \\
(\text { Bcl-xL ) } \\
591 \text { bp } \\
(\text { Bcl-xS) }\end{array}$ \\
\hline Bax & 5'-GGCCCACCAGCTCTGAGCAGA-3' & 5'-GCCACGTGGGCGTCCCAAAGT-3' & $479 \mathrm{bp}$ \\
\hline GAPDH & 5'-TGGAAGGACTCATGACCACAG-3' & 5'-CTGGTGCTCAGTGTAGCCCAG-3' & $475 \mathrm{bp}$ \\
\hline p53 & 5'-GCGTCTTAGAGACAGTTGCCT-3' & 5'-GGATAGGTCGGCGGTTCATGC-3' & $458 \mathrm{bp}$ \\
\hline PARP-1 & 5'-AGGCCCTAAAGGCTCAGAAT-3' & 5'-CTAGGTTTCTGTGTCTTGAC-3' & $470 \mathrm{bp}$ \\
\hline $\mathrm{NF \kappa B}$ & 5'AACAAAATGCCCCACGGTTA-3' & 5'-GGGACGATGCAATGGACTGT-3' & $113 \mathrm{bp}$ \\
\hline
\end{tabular}


753 Table 2: Effect of different parts of $T$. pallida extracts on hematological parameters in EAC mice.

\begin{tabular}{|c|c|c|c|}
\hline Treatments & $\begin{array}{l}\text { Hb content } \\
\text { (g/dl) }\end{array}$ & $\begin{array}{l}\text { Total RBC } \\
\left(\text { cells/ml x 10 }{ }^{6}\right)\end{array}$ & $\begin{array}{c}\text { Total WBC } \\
\left(\text { cells/ml x 10 }{ }^{6}\right)\end{array}$ \\
\hline $\begin{array}{l}\text { Group I (normal } \\
\text { saline) }\end{array}$ & $13.77 \pm 0.39$ & $5.49 \pm 0.51$ & $6.13 \pm 0.46$ \\
\hline Group II (control) & $8.6 \pm 0.13^{*}$ & $3.29 \pm 1.13^{*}$ & $12.03 \pm 0.63^{*}$ \\
\hline Group III (TPL) & $11.88 \pm 0.32^{* *}$ & $4.83 \pm 0.17^{* *}$ & $8.24 \pm 0.20^{* * *}$ \\
\hline Group IV (TPF) & $11.60 \pm 0.53^{* *}$ & $4.47 \pm 0.67^{* *}$ & $8.76 \pm 0.72^{* *}$ \\
\hline Group V (TPSB) & $10.98 \pm 0.09^{* *}$ & $4.51 \pm 0.44^{* *}$ & $8.49 \pm 0.83^{* *}$ \\
\hline Group VI (TPRB) & $8.9 \pm 0.11^{* *}$ & $3.79 \pm 0.84^{* *}$ & $9.76 \pm 0.04^{* *}$ \\
\hline $\begin{array}{l}\text { Group VII } \\
\text { (bleomycin) }\end{array}$ & $12.13 \pm 0.24$ & $5.07 \pm 0.79$ & $7.88 \pm 0.26$ \\
\hline Standard & & & \\
\hline
\end{tabular}

754 Number of mice in each case $(n=4)$; the results were shown as mean \pm SEM. The results were 755 shown as mean \pm SEM. Where significant values are, $* \mathrm{P}<0.05$ and $* * \mathrm{P}<0.01$ when compared 756 with EAC control group. 
758 Table 3: Effect of different parts of T. pallida on EAC cell-induced tumor cell growth inhibition in

759 mice.

\begin{tabular}{|c|c|c|c|c|}
\hline $\begin{array}{c}\text { Name of } \\
\text { Experiment }\end{array}$ & $\begin{array}{l}\text { Nature of the } \\
\text { drug }\end{array}$ & $\begin{array}{c}\text { Dose mg/kg/day } \\
\text { (i.p ) }\end{array}$ & $\begin{array}{l}\text { No. of EAC cells in } \\
\text { mice on day } 6 \text { after } \\
\text { tumour cell } \\
\text { inoculation }\end{array}$ & $\begin{array}{c}\% \text { of cell } \\
\text { growth inhibition }\end{array}$ \\
\hline $\begin{array}{l}\text { EAC cell bearing } \\
\text { mice }\end{array}$ & Control & --- & $(5.41 \pm 0.40) \times 10^{7 * *}$ & \\
\hline Bleomycin & Standard & $0.3 \mathrm{mg} / \mathrm{kg}$ & $(0.91 \pm 0.08) \times 10^{7 * * *}$ & 83.10 \\
\hline TPL & Experimental & $100 \mathrm{mg} / \mathrm{kg}$ & $(1.53 \pm 0.10) \times 10^{7 * * *}$ & 71.71 \\
\hline TPF & Experimental & $100 \mathrm{mg} / \mathrm{kg}$ & $(1.81 \pm 0.14) \times 10^{7 *}$ & 66.42 \\
\hline TPSB & Experimental & $100 \mathrm{mg} / \mathrm{kg}$ & $(1.83 \pm 0.17) \times 10^{7 * *}$ & 63.13 \\
\hline TPRB & Experimental & $100 \mathrm{mg} / \mathrm{kg}$ & $(2.29 \pm 0.15) \times 10^{7 *}$ & 57.62 \\
\hline
\end{tabular}

760 Number of mice in each case $(n=4)$; the results were shown as mean \pm SEM. Where significant

761 values are, $* \mathrm{P}<0.05, * * \mathrm{P}<0.01$ and $* * * \mathrm{P}<0.001$ when $(\mathrm{EAC}+\mathrm{TPL} / \mathrm{TPF} / \mathrm{TPSB} / \mathrm{TPRB} /$

762 Standard) treated mice compared with EAC bearing control mice (EAC bearing only). 
764 Table 4: Chemical profiles of the major peaks and identified compounds in TPL.

\begin{tabular}{|c|c|c|c|c|c|}
\hline Peak no & $\mathbf{R T}^{\mathrm{a}}$ & UV data $(\lambda \max )$ & $\mathrm{ESI}[\mathrm{M}+\mathbf{H}]^{+}$ & Tentative compounds ${ }^{b}$ & $\operatorname{RPA}^{\mathbf{c}}(\%)$ \\
\hline 1 & 1.37 & 225,273 & 195.25 & D-glucuronic acid & 14.7 \\
\hline 2 & 7.91 & 214,290 & & unknown & 3.6 \\
\hline 3 & 9.12 & $430,330,278$ & 434.21 & pelargonidin-3-O-glucoside & 1.7 \\
\hline 4 & 10.10 & 255,353 & 465.12 & quercetin-3-glucoside & 25.2 \\
\hline 5 & 11.31 & $257,301,354$ & 507.45 & $\begin{array}{l}\text { Quercetin-3-O-(2"'-O- } \\
\text { acetyl)glucoside }\end{array}$ & 2.9 \\
\hline 6 & 12.48 & 208,280 & & unknown & 1.6 \\
\hline 7 & 13.79 & 214,274 & & unknown & 2.8 \\
\hline 8 & 28.33 & 273,481 & 243.24 & Lapachol & 1.7 \\
\hline 9 & 29.78 & 274,483 & 243.23 & Beta-lapachone & 3.1 \\
\hline 10 & 30.85 & 228,277 & 614.47 & Coumaringlucoside & 1.7 \\
\hline
\end{tabular}

$765{ }^{\mathrm{a}}$ Retention time (min).

$766{ }^{\mathrm{b}}$ Compounds tentatively identified based on parent molecular ions, UV values, retention times, and

767 elution order, as well as the fragmentation pattern described in the literature.

$768{ }^{\mathrm{c}}$ Relative peak area percentage (peak area relative to the total peak area\%).

769

770

771

772

773

774

775

776

777

778

779 
780 Table 5 Antioxidant and anticancer activities of identified compounds with binding protein

781 PDB:1R4U and PDB: 5IAE.

\begin{tabular}{|c|c|c|c|c|c|c|}
\hline \multirow[t]{2}{*}{ Compounds Name } & \multicolumn{3}{|c|}{ 1R4U } & \multicolumn{3}{|c|}{ 5IAE } \\
\hline & $\begin{array}{c}\text { Docking } \\
\text { score }\end{array}$ & $\begin{array}{c}\text { Glide } \\
\text { emodel }\end{array}$ & $\begin{array}{c}\text { Glide } \\
\text { energy }\end{array}$ & $\begin{array}{c}\text { Docking } \\
\text { score }\end{array}$ & $\begin{array}{c}\text { Glide } \\
\text { emodel }\end{array}$ & $\begin{array}{c}\text { Glide } \\
\text { energy }\end{array}$ \\
\hline D-glucuronic acid & -5.54 & -35.243 & -25.4 & -5.287 & -43.462 & -30.721 \\
\hline $\begin{array}{l}\text { Pelargonidin-3-O- } \\
\text { glucoside }\end{array}$ & -6.42 & -59.752 & -45.451 & -6.566 & -59.813 & -46.383 \\
\hline Quercetin-3-glucoside & -5.396 & -53.77 & -42.743 & -5.238 & -57.228 & -45.294 \\
\hline Lapachol & -4.678 & -38.195 & -30.876 & -4.092 & -32.423 & -26.351 \\
\hline Beta-lapachone & -5.094 & -33.839 & -22.979 & -4.788 & -37.676 & -27.337 \\
\hline
\end{tabular}

782

783

784

785

786

787

788

789

790

791

792

793

794

795

796 


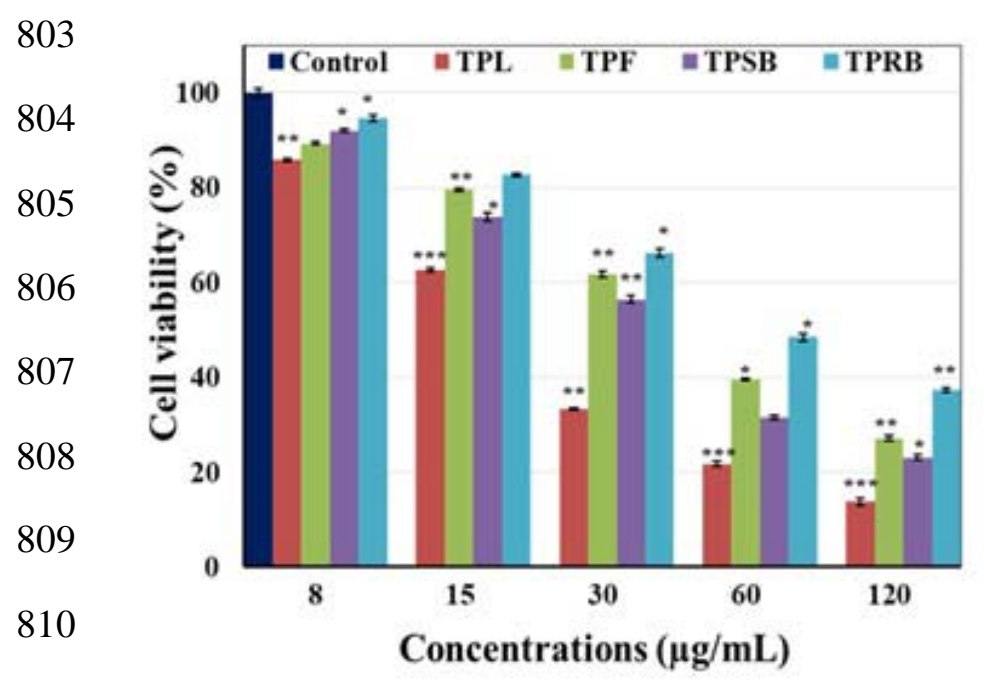

\section{B}

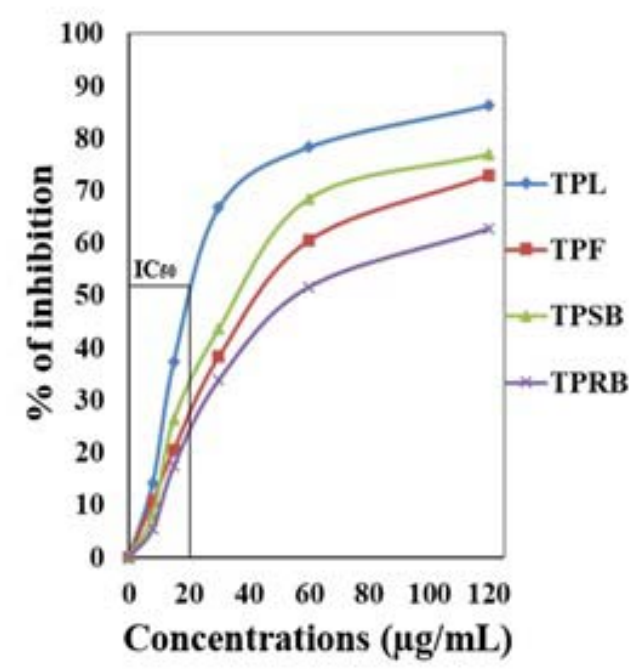

814 Figure 1. (A) Observation of EAC cells growth inhibition by T. pallida extracts. The cell 815 proliferation was measured by the MTT assay $(n=3$, mean \pm SEM) after cells were treated with 816 various doses of sample extracts and without samples for $24 \mathrm{~h}$ in $\mathrm{CO}_{2}$ incubator at $37{ }^{\circ} \mathrm{C} .{ }^{*} \mathrm{p}<0.05$, $817{ }^{* *} \mathrm{p}<0.01$ and ${ }^{* * *} \mathrm{p}<0.001$ as compared sample-treated EAC cells with untreated control. (B) $\mathrm{IC}_{50}$ of 818 T. pallida extracts (TPL, TPF, TPSB and TPRB) determined from EAC cell growth inhibition 819 activity in MTT assay. Data expressed as mean $\pm \mathrm{SEM})(\mathrm{n}=3)$ for all tested dosages. 


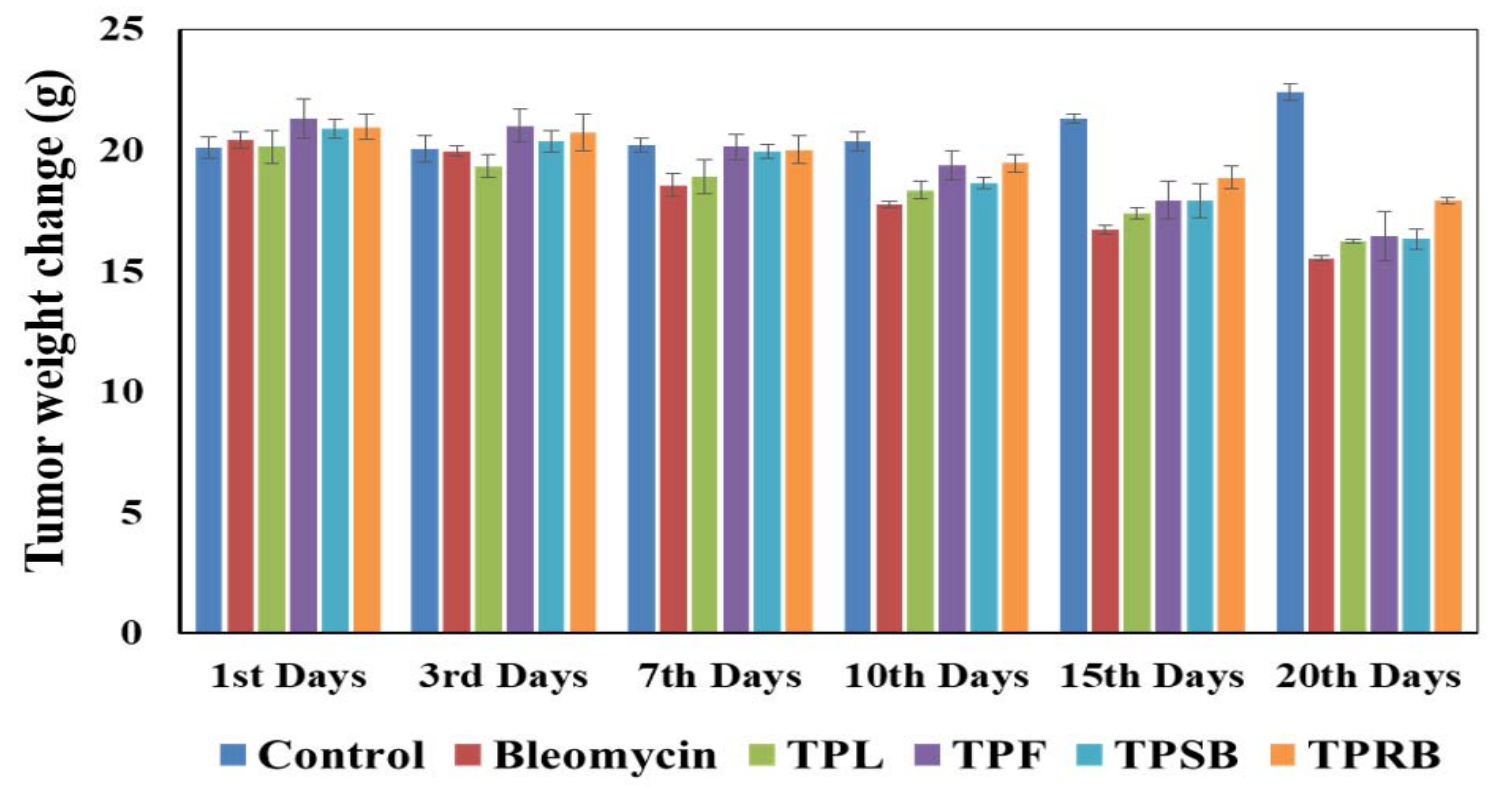

823

824 Figure 2. .Effect of methanol extract of different parts of T. pallida on tumor weight of EAC cell

825 bearing mice at different time points of the experiment. Values are mean $\pm \operatorname{SEM}(n=4)$.

826

827

828

829

830

831

832 
A

836

838

840

841

842

843

844

845

846

847

848

849

850

851 852

列
B

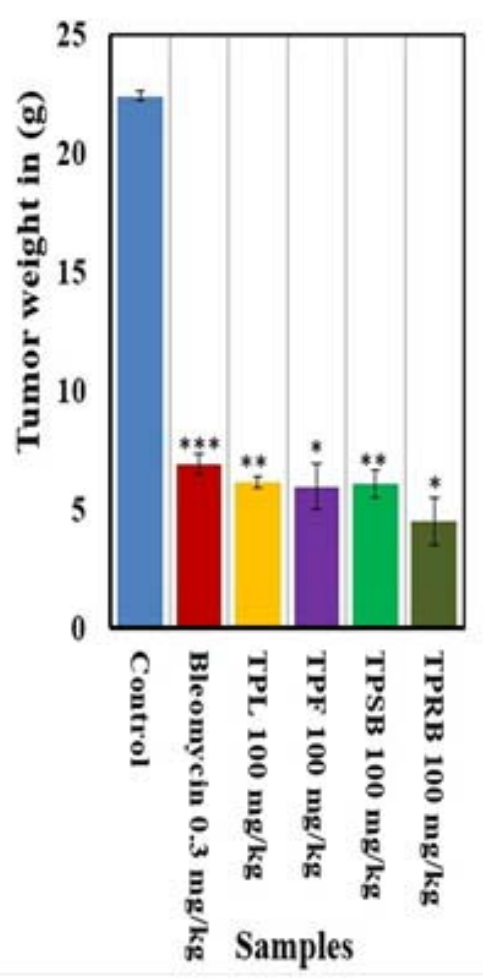

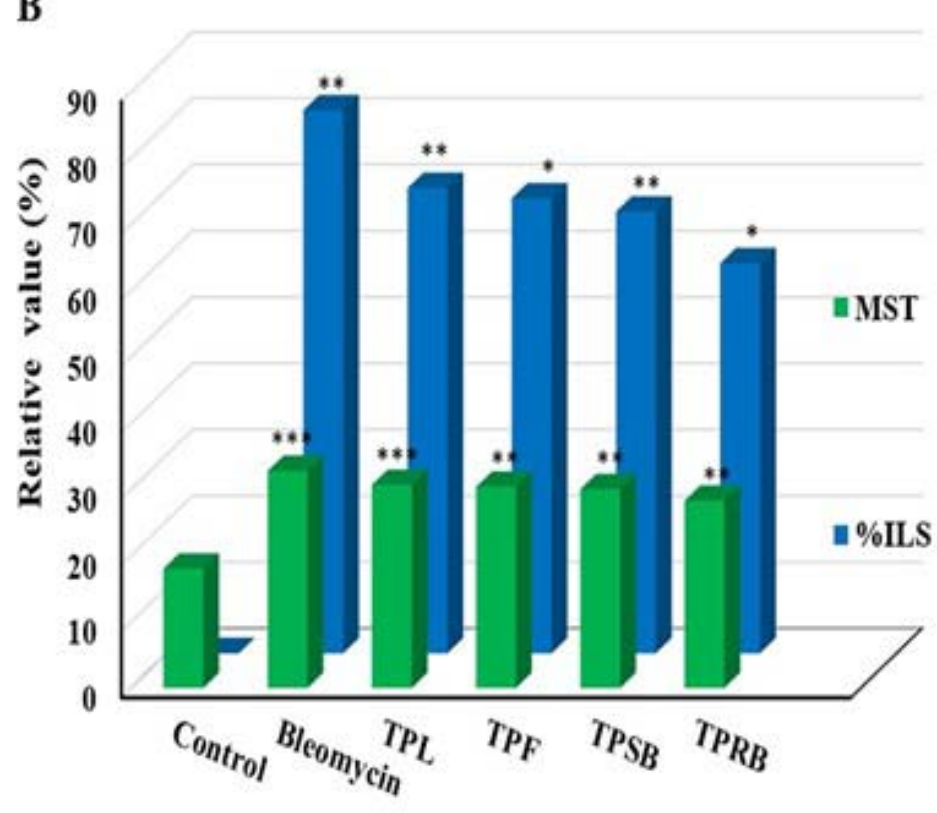

Name of samples 

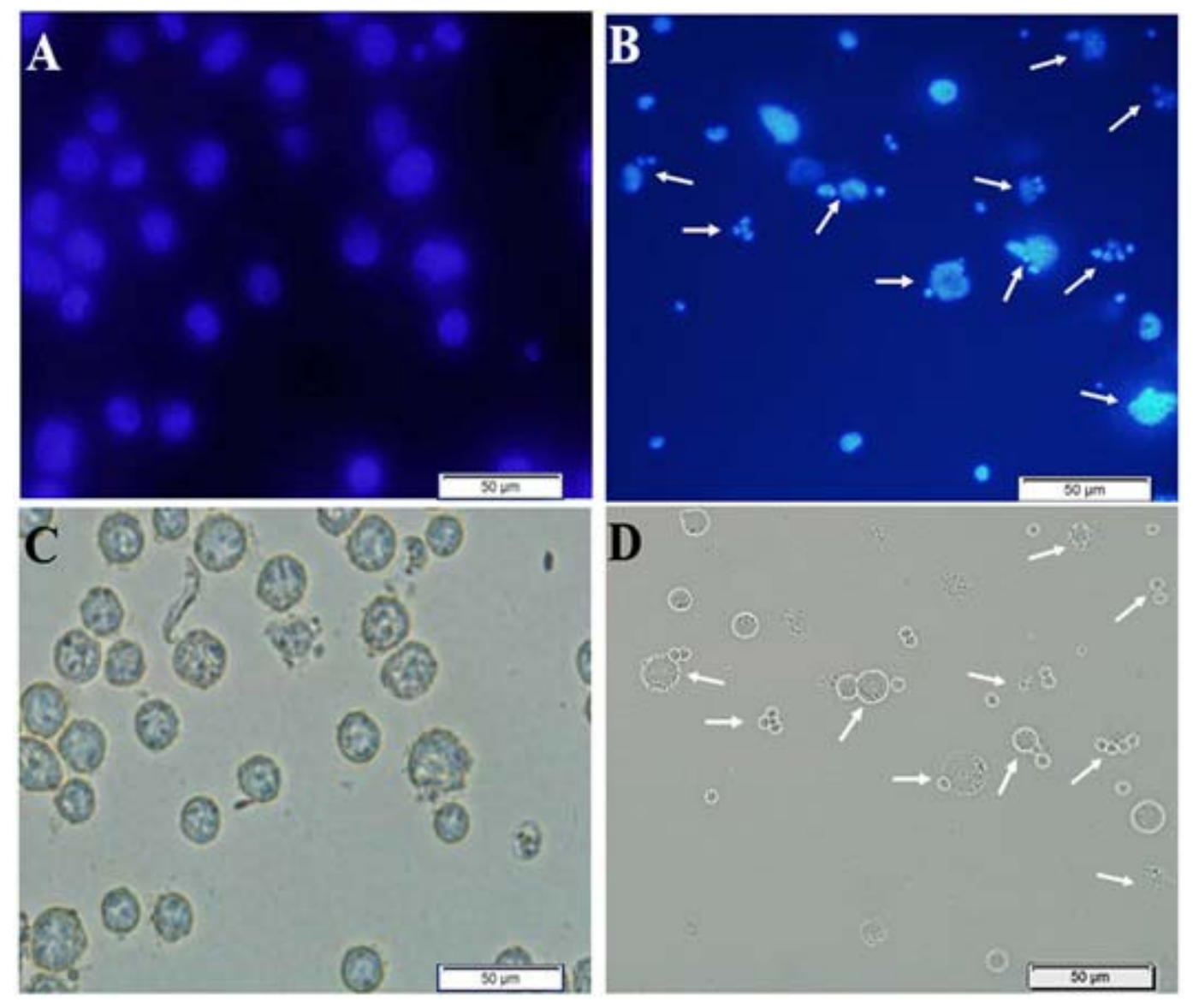

865 Figure 4. Morphological observation of TPL-induced apoptosis in Hoechst 33342 stained EAC

866 cells by optical and fluorescence microscopy (Olympus iX71). Cells were collected from untreated

867 EAC bearing mice demonstrated in A (fluorescence) and C (optical) and TPL treated EAC bearing

868 mice demonstrated in B (fluorescence) and D (optical). Arrows indicate apoptotic features

869 (condensed chromatin and nuclear fragmentation). 


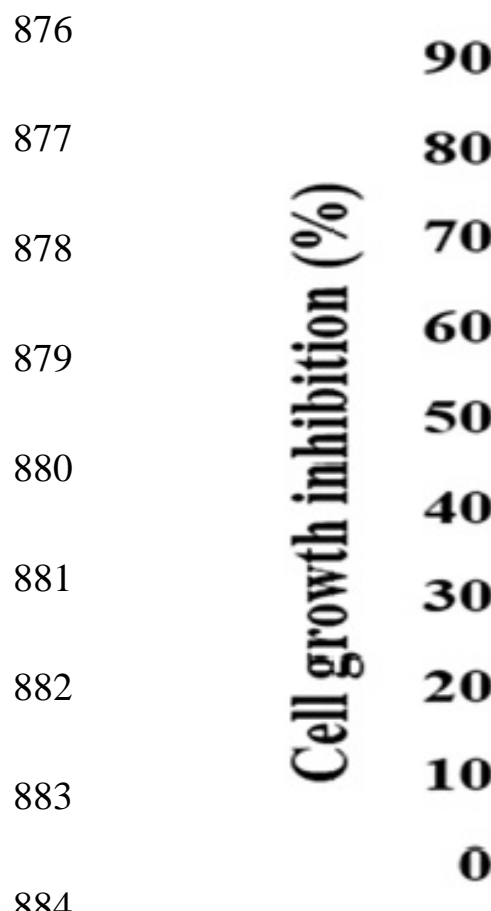

884

885

886

888

889

890

891 cells with or without $2 \mathrm{~mol} / \mathrm{mL}$ z-DEVD-fmk and z-IETD-fmk at $37^{\circ} \mathrm{C}$ for $2 \mathrm{~h}$, cells were incubated

892 for $24 \mathrm{~h}$ at the said environment, then cell growth inhibition was determined by MTT assay ( $\mathrm{n}=3$,

893 mean \pm SEM). Significant values are, ${ }^{*} \mathrm{P}<0.05,{ }^{* * *} \mathrm{P}<0.01$ and ${ }^{* * *} \mathrm{P}<0.001$ when TPL treated EAC

894 cells are compared with TPL + Cas-3/8 inhibitor treated EAC cells.
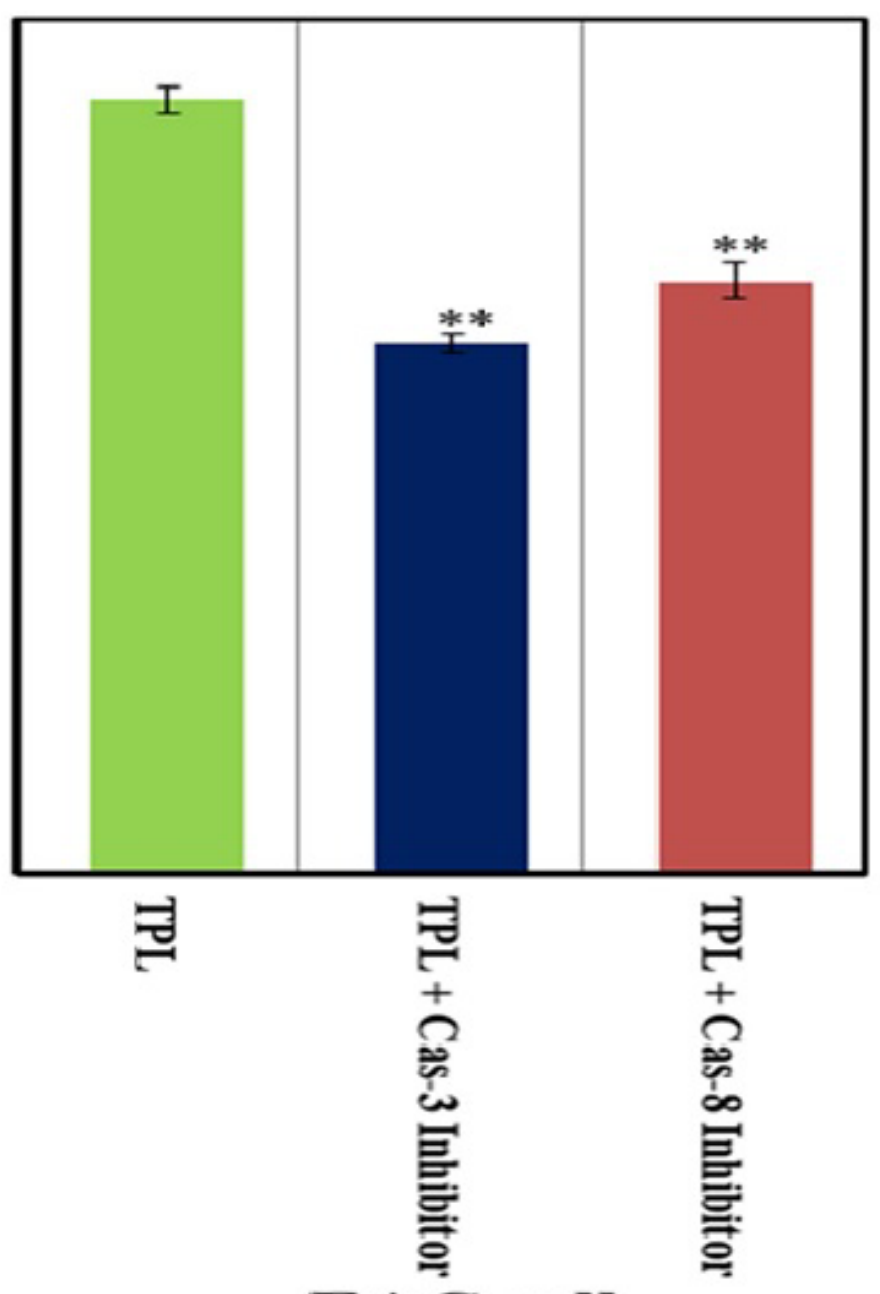

EAC cell

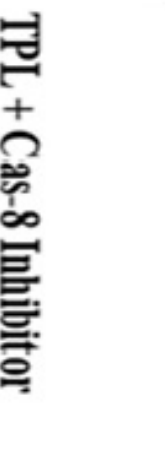

895

896

897 
A

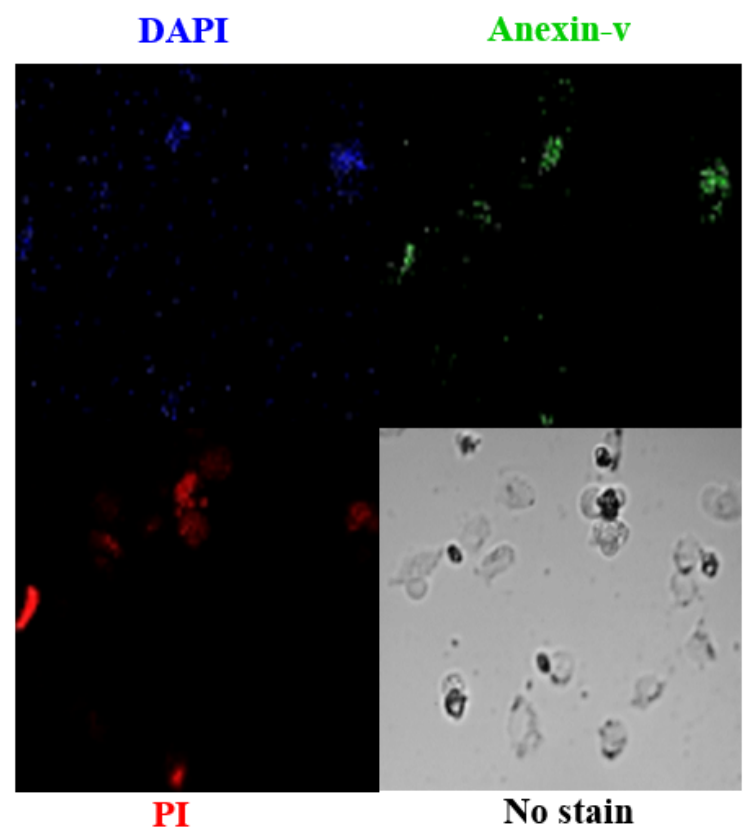

Untreated HeLa Cells
B

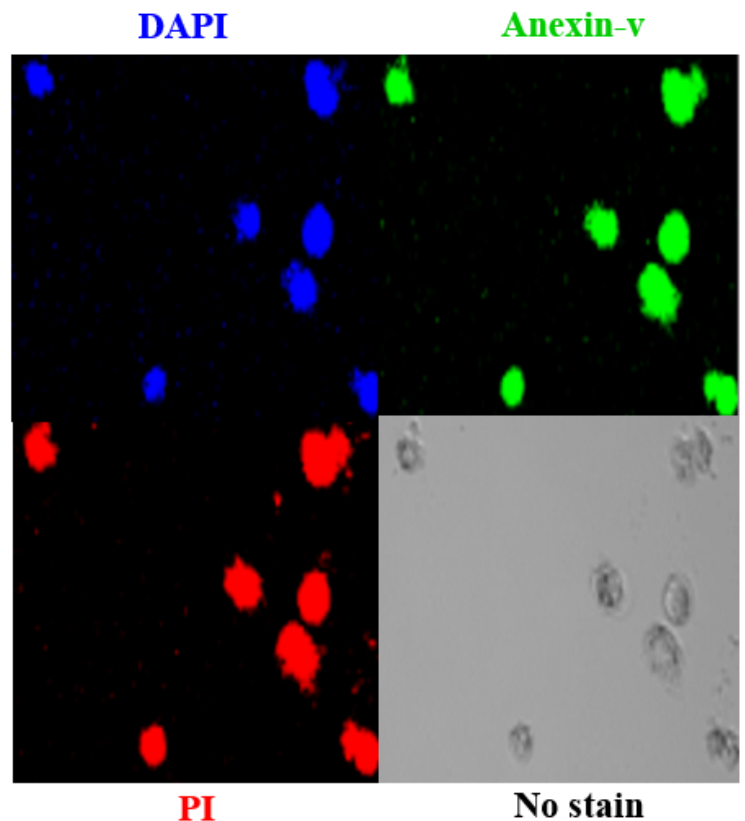

TPL-treated Cells

Figure 6..Representative images of DAPI, Annexin V-FITC and PI triple florescence staining on

902 HeLa cell apoptosis. Cell nucleus was visualized by blue signal due to DAPI, Annexin V-FITCwas

903 visualized by green signal, and PI was visualized by red signal.

904

905

906

907

908

909 
914

915

916

917

918

919

920

921

922

923

924

925

926

927

928

929

930

931

932

933
A

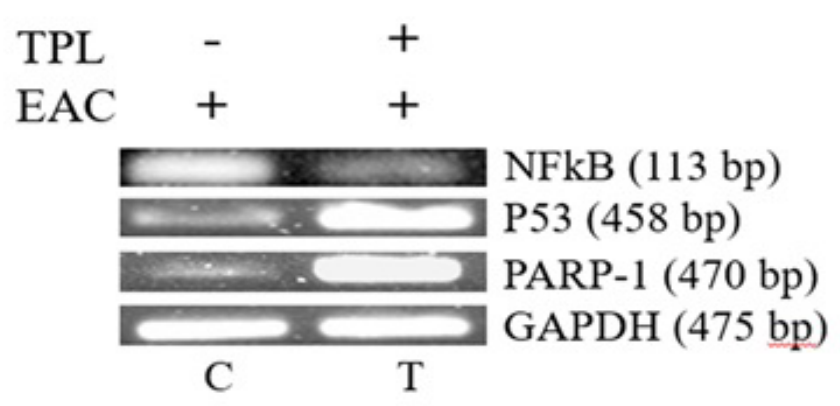

B

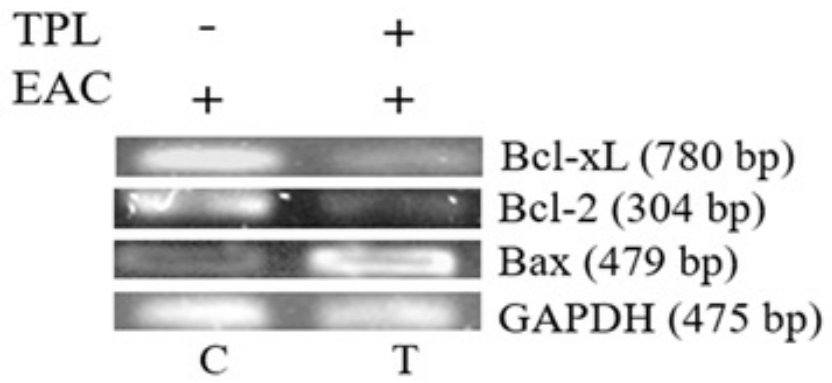

C (i)

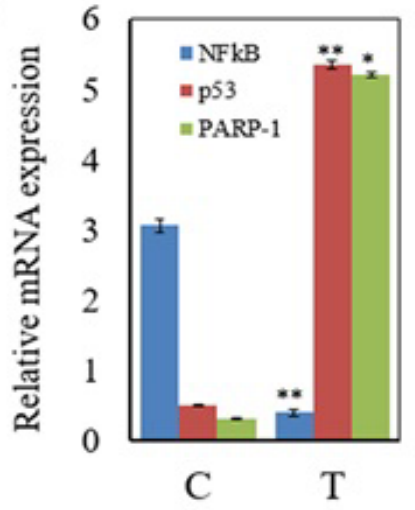

C (ii)

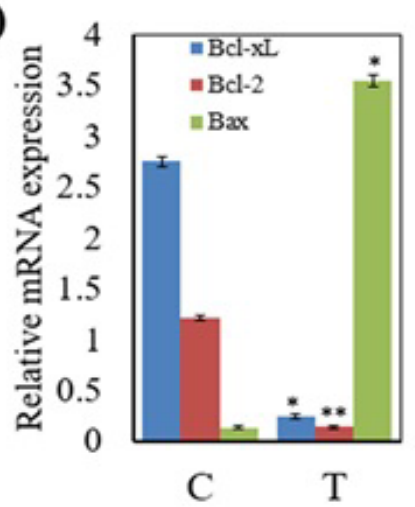

Figure 7. Analysis of mRNA expression levels of pro-and anti-apoptotic genes. Expression of (A) NFk-B, p53, and PARP-1 (upper panel) and (B) Bcl-xL, Bcl-2, and Bax genes (lower panel) was analyzed by semi-quantitative RT-PCR in untreated EAC mice (control) and TPL-treated EAC mice. The positions of the genes along with their length are indicated on the left in bp. The bottom panel shows the PCR products of GAPDH as a control in both the panels. GAPDH transcript was used to normalize the expression levels. (C) (i), upper and (ii) lower panels indicate relative expression of (A, upper panel) NFkB, p53, and PARP-1 and (B, lower panel) Bcl-xL, Bcl-2, and Bax genes determined by a densitometric method. Error bars indicate the S.D. from three different experiments. $\mathrm{C}$ and $\mathrm{T}$ indicate untreated (control) and TPL-treated mice, respectively. The asterisks indicate that TPL treated tumor bearing mice is significantly different $\left({ }^{*} \mathrm{p}<0.05,{ }^{* *} \mathrm{p}<0.01\right.$, and 
$\mathbf{A}$

938

939

940

941

942

943

944

945

946

947

948

949

950

951

952

953

954

955

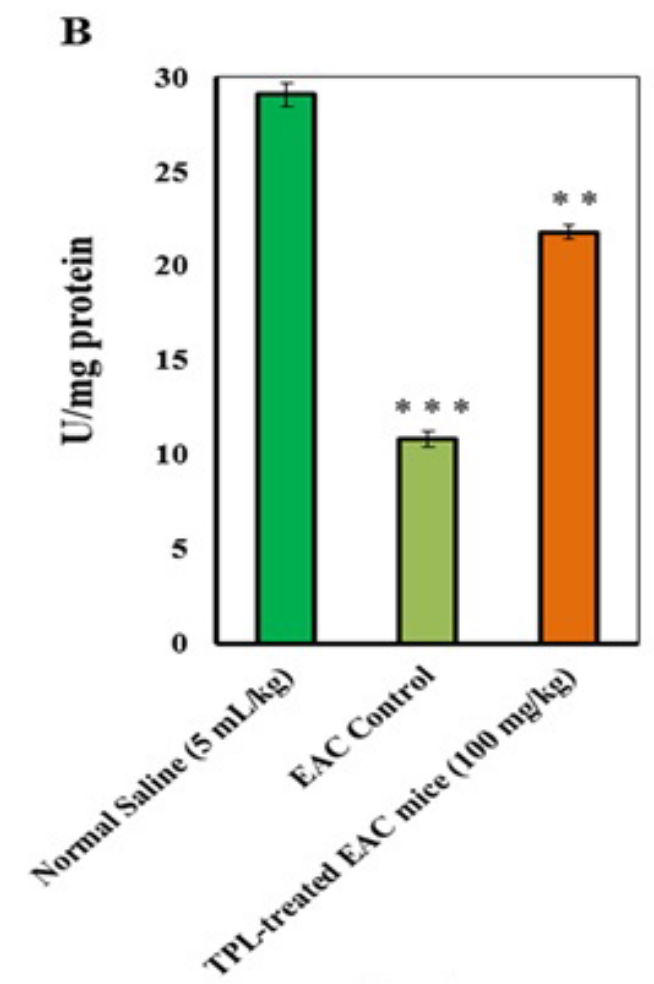

Catalase

Catalase

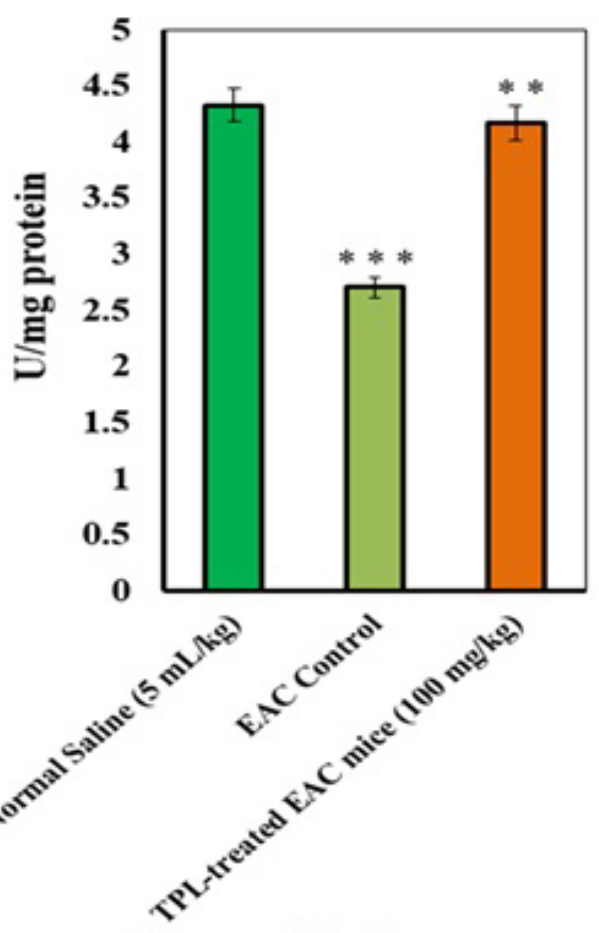

Superoxide dismutase 
964

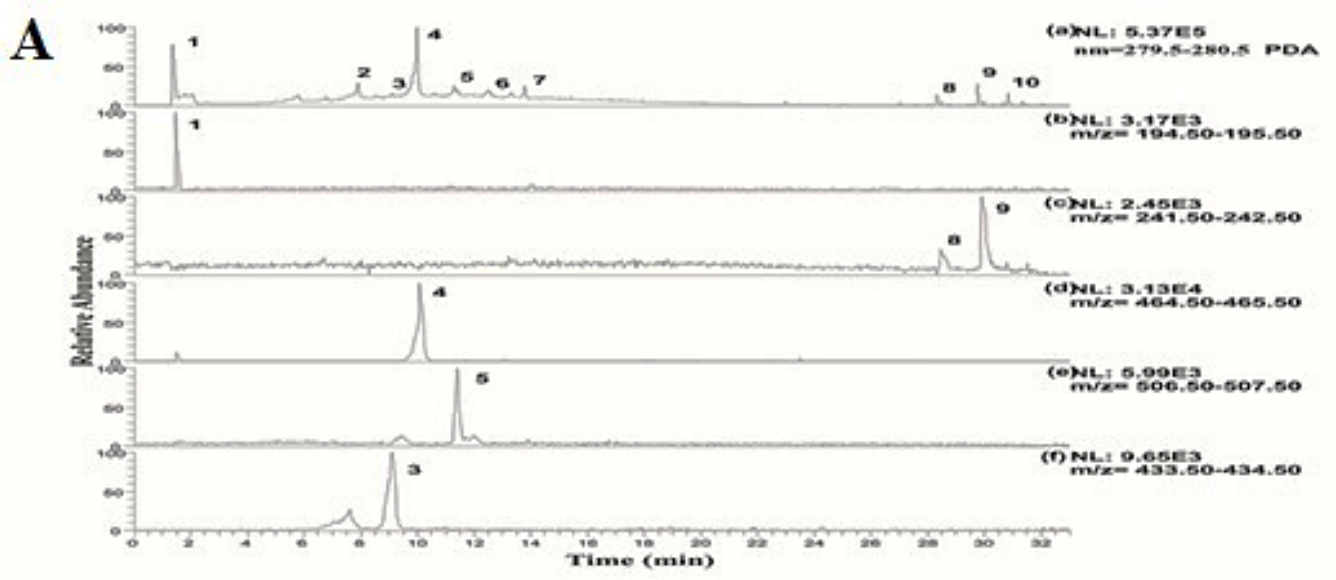

965

B

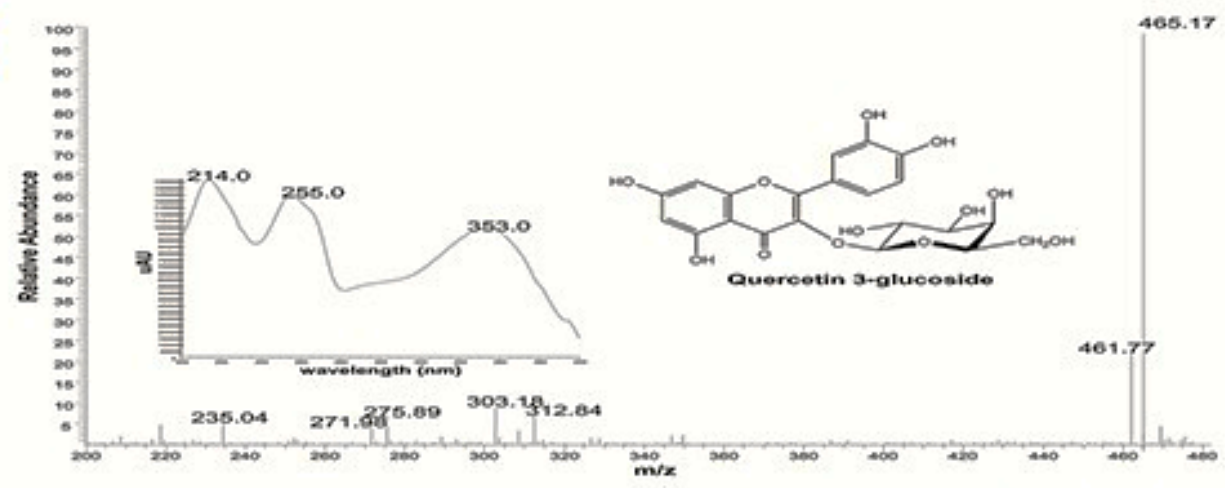

969

970

971 Figure 9. (A) HPLC profile of TPL. (a) HPLC-PDA spectrum of the major peaks at 280nm with

972 tentatively identified compounds (1-10), (b-f) Selected ion chromatogram (parent ion) for the peak

$9738,9,4,5 \& 3$.(B) Mass spectrum of the major peak with UV spectra and structure of the quercetin

974 3-glucoside.

975

976

977 
980

A

981

982

983

984

985

986

987

988

989

990

991

992

993

994

995

996

997

998

999

1000

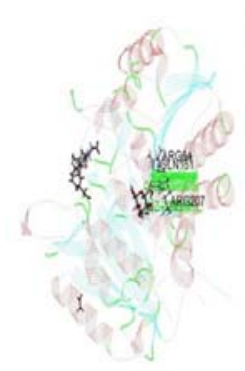

D

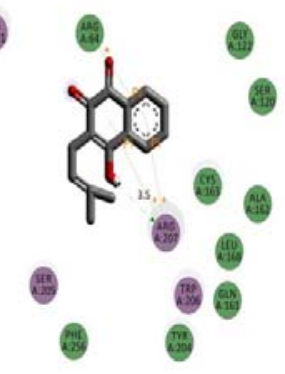

B

C
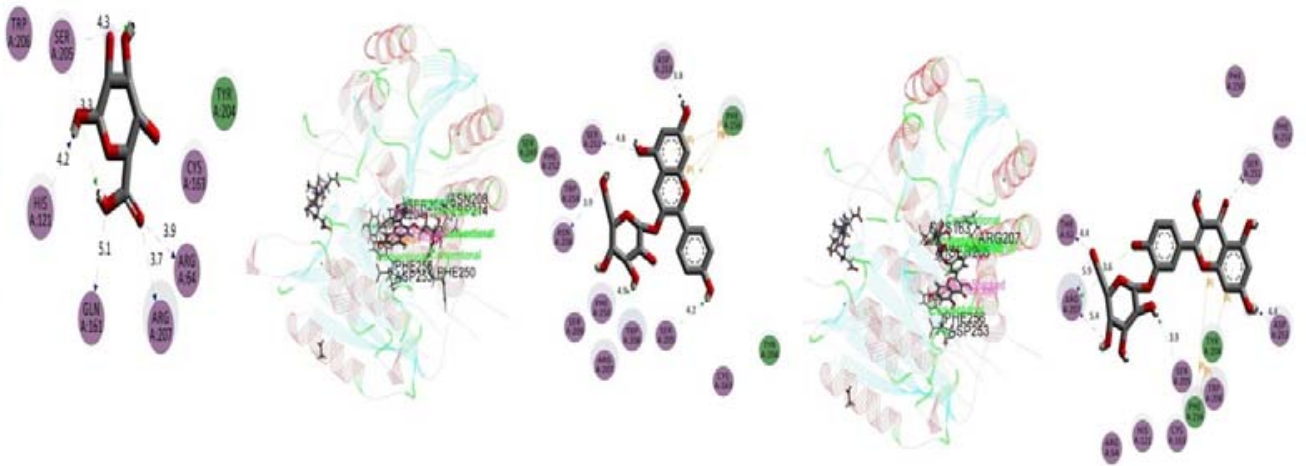

E

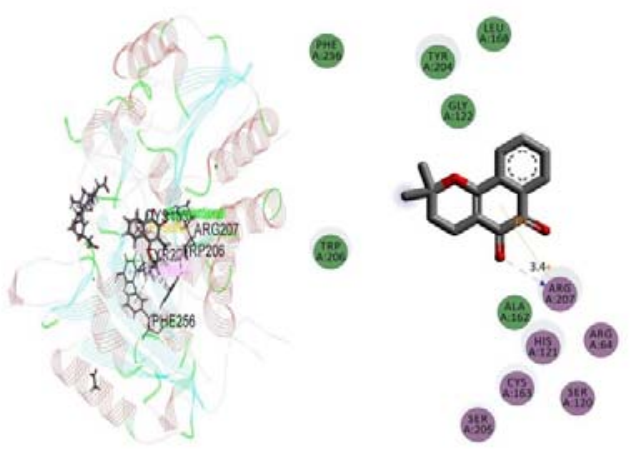

1001

1002 
1004

1005

A

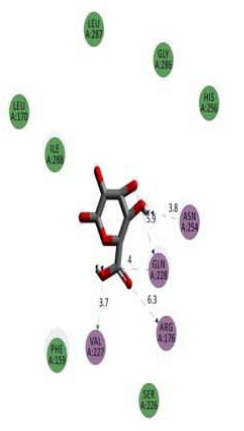

B

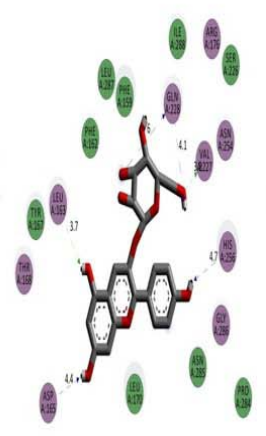

C

1006

1007

1008

1009

1010

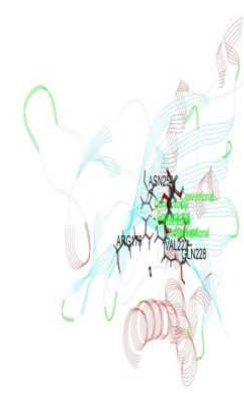

1011

1012

D
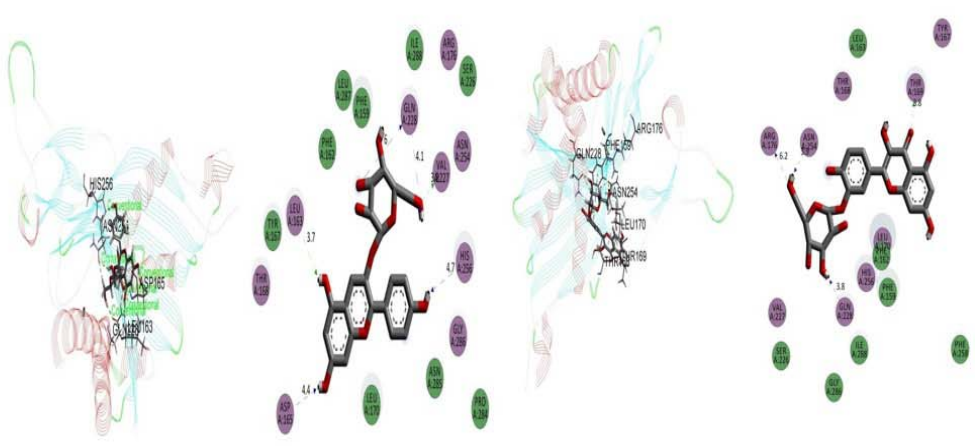

1013

1014

1015

1016

1017

1018

1019

1020

1021

1022

1023 Figure 11. Best ranked poses and 2D interactions of (A) D-glucuronic acid (B) Pelargonidin-3-O-

1024 glucoside (C)Quercetin-3-glucoside(D) Lapacholand (E) Beta-lapachone with HeLa cell receptor

1025

(PDB: 5IAE) for anticancer activity.

1026

1027

1028 
bioRxiv preprint doi: https://doi.org/10.1101/2021.01.11.426226; this version posted January 11, 2021. The copyright holder for this preprint (which was not certified by peer review) is the author/funder. All rights reserved. No reuse allowed without permission.

1029

1030 